San Jose State University

SJSU ScholarWorks

Master's Theses

Master's Theses and Graduate Research

1995

\title{
Illustrations of the destructive powers of traditional pedagogy as seen in the novels of Julien Green
}

Joann Reeves Christiansen

San Jose State University

Follow this and additional works at: https://scholarworks.sjsu.edu/etd_theses

\section{Recommended Citation}

Christiansen, Joann Reeves, "Illustrations of the destructive powers of traditional pedagogy as seen in the novels of Julien Green" (1995). Master's Theses. 983.

DOI: https://doi.org/10.31979/etd.hvz4-9hp3

https://scholarworks.sjsu.edu/etd_theses/983

This Thesis is brought to you for free and open access by the Master's Theses and Graduate Research at SJSU ScholarWorks. It has been accepted for inclusion in Master's Theses by an authorized administrator of SJSU ScholarWorks. For more information, please contact scholarworks@sjsu.edu. 


\section{INFORMATION TO USERS}

This manuscript has been reproduced from the microfilm master. UMI films the text directly from the original or copy submitted. Thus, some thesis and dissertation copies are in typewriter face, while others may be from any type of computer printer.

The quality of this reproduction is dependent upon the quality of the copy submitted. Broken or indistinct print, colored or poor quality illustrations and photographs, print bleedthrough, substandard margins, and improper alignment can adversely affect reproduction.

In the unlikely. event that the author did not send UMI a complete manuscript and there are missing pages, these will be noted. Also, if unauthorized copyright material had to be removed, a note will indicate the deletion.

Oversize materials (e.g., maps, drawings, charts) are reproduced by sectioning the original, beginning at the upper left-hand comer and contimuing from left to right in equal sections with small overlaps. Each original is also photographed in one exposure and is included in reduced form at the back of the book.

Photographs included in the original manuscript have been reproduced xerographically in this copy. Higher quality $6^{n} \times 9^{n}$ black and white photographic prints are available for any photographs or illustrations appearing in this copy for an additional charge. Contact UMI directly to order.

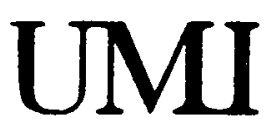

A Bell \& Howell information Company 



\title{
ILLUSTRATIONS OF THE DESTRUCTIVE POWERS OF TRADITIONAL PEDAGOGY AS SEEN IN THE NOVELS OF JULIEN GREEN
}

\author{
A Thesis \\ Presented to \\ The Faculty of the Department of Foreign Languages \\ San Jose State University
}

In Partial Fulfillment

of the Requirements for the Degree

Masters of Arts

\author{
by \\ Joann Reeves Christiansen \\ May 1995
}


UMI Number: 1374574

Copyright 1995 by Christiansen, Joann Reeves

All rights reserved.

UMI Microform 1374574

Copyright 1995, by UMI Company. All rights reserved.

This microform edition is protected against unauthorized copying under Title 17, United States Code.

\section{UMI}

300 North Zeeb Road

Ann Arbor, MI 48103 
APPROVED FOR THE DEPARTMENT OF FOREIGN LANGUAGES

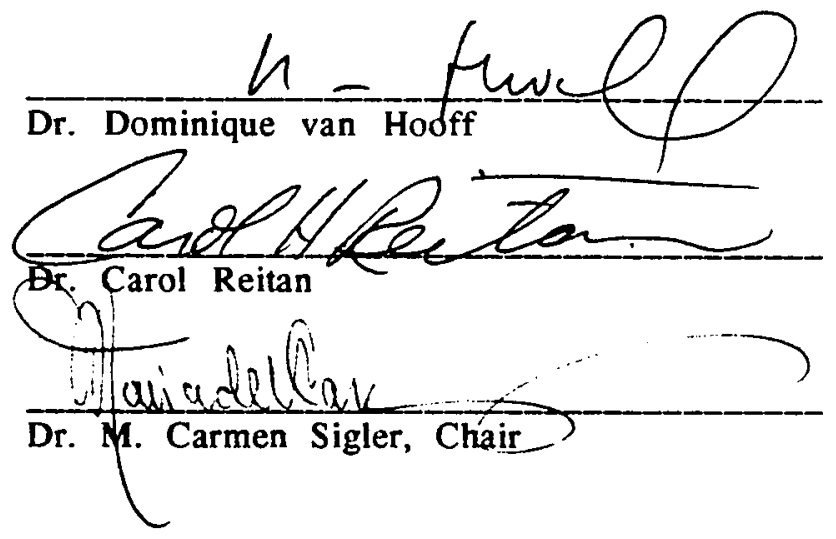

APPROVED FOR THE UNIVERSITY

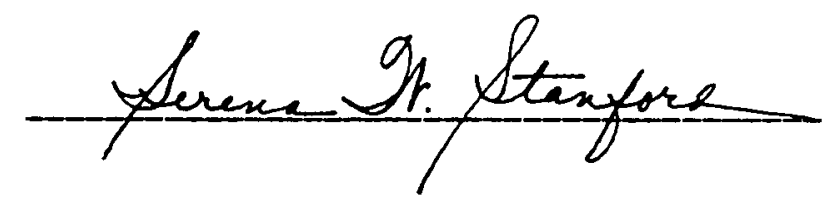


(C) 1995

Joann Reeves Christiansen

ALL RIGHTS RESERVED 


\section{ABSTRACT \\ ILLUSTRATIONS OF THE DESTRUCTIVE POWERS OF TRADITIONAL PEDAGOGY AS SEEN IN THE NOVELS OF JULIEN GREEN \\ by Joann Reeves Christiansen}

The purpose of this thesis about Julien Green, an American author of French expression, is to offer a possible explanation for the violence, anger, depression and madness that so typify his novels. It is understood that the findings contained herein offer only a partial explanation; nevertheless, they demonstrate a direct link between the suffering of Green's characters and their having been raised according to the principles of traditional pedagogy. There is enough evidence in the author's journals to believe he himself was raised according to the same system. One finds descriptions of his characters either administering or receiving the identical punishments he describes having observed or endured as a child. It is highly probable that Julien Green's own experiences shaped his ideas about parent-child relationships as well as the suffering that children so raised suffer as adults. 


\section{Acknowledgments}

To my husband Shanon for his unwavering support

To Catherine, Suzanne, and Caryn

for their encouragement

$$
\text { and }
$$

To Caryn for hours spent proof-reading and formating the final manuscript

and

to Dominique Van Hooff who so willingly shared her knowledge and expertise 


\title{
ILLUSTRATIONS OF THE DESTRUCTIVE POWERS OF TRADITIONAL PEDAGOGY
}

\author{
AS SEEN IN THE NOVELS OF \\ JULIEN GREEN
}

TABLE OF CONTENTS

\begin{abstract}
Page

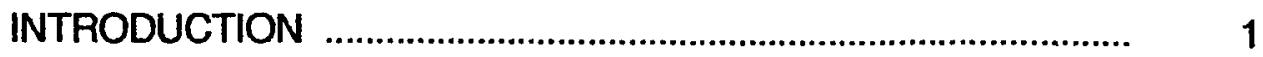

Chapter
\end{abstract}

1. TRADITIONAL PEDAGOGY AS SEEN IN GREEN'S LIFE AND FICTITIOUS CHARACTERS....................................... 9

2. THE ROLE OF RELIGION IN THE CREATION OF THE FAMILY PRISON ……………............................................ 28

3. EMOTIONALLY ABANDONED CHILDREN IN THE WORLD OF JULIEN GREEN .

4. PRISON WITHOUT WALLS: TIMIDITY, A SENSE OF INFERIORITY OR SHAME

5. FROM TRADITIONAL PEDAGOGY TO VIOLENCE AND DEATH

CONCLUSION.. 105

BIBLIOGRAPHY 110 


\section{INTRODUCTION}

One can not read the works of Julien Green without being struck by the emotional instability of so many of his characters. Driven, haunted, obsessed, violent or suffering from extreme timidity, they draw the reader into their tormented worlds and hold him there almost against his will as a witness to the tragic unraveling of their lives. How can we account for these intense emotions - the shame, the uncontrollable desires, the fear, and the violence?

The answers to this question are to be found in Green's life, novels and journals. He recognized and described in a truly unforgettable manner, the traumatism of children suffering from lack of affection as well as from the strict, punitive, shaming methods of child rearing advocated by traditional pedagogy. The result of such trauma is men and women who suffer from profound lifelong neurosis and psychosis such as those exhibited by the majority of Green's characters.

Most middle and upper-middle class parents in the western world before the 1960 's believed in and practiced to a greater or lesser degree, traditional pedagogy. This could account for the profound impact that Green's novels have on those who read them. The reader identifies with the characters who are experiencing thoughts and feelings that he has heretofore believed no one besides himself had ever known. Julien Green is amazingly objective in his depiction of the family. In fact, few writers have been able to write so honestly of 
parent-child relationships. Shakespeare did it with Lord and Lady Capulet in Romeo and Juliet and also with King Lear; Mark Twain was criticized for it but generally, novelists or playwrights have idealized parents. After having read Mont Cinère, François Mauriac declared: "Enfin un roman objectif" (Saint Jean 54-55).

Beginning with the studies of Freud, the psychological community had knowledge of the fact that the traumatism of childhood can have repercussions on the adult; but it was not until the 1960's that a German psychologist, Alice Miller, and a few of her contemporaries began to seriously study what Green had already been describing, evidently unintentionally, since the 1920's: the effects of a rigid and puritan upbringing on one's life. Ms. Miller, haunted since the end of the second world war by questions about the causes of hatred and violence, began searching for the roots of these phenomena. She found an initial explanation in the education of children. In her book, C'est pour ton bien, she exposes what she calls the "pédagogie noire":

II semble qu'au fur et à mesure que l'on se rapproche de l'époque moderne, la mutilation, l'exploitation et la persécution physiques de l'enfant aient été supplantées par une cruauté psychique, que l'on peut en outre présenter sous la dénomination bienveillante et mystificatrice "d'éducation". Etant donné que, chez de nombreux peuples, l'éducation commence dès le berceau, dans la phase de la relation encore symbiotique avec la mère, ce conditionnement des plus précoces ne permet guère de connaître la situation réelle de l'enfant. Par la suite, le besoin de l'amour parental interdit également à l'enfant de se rendre compte du traumatisme qui persiste souvent une vie entière, caché derrière l'idéalisation des parents établie 
dans les premières années. (15-16)

At the beginning of the century, when Sigmund Freud was formulating his theories of human behavior, it was forbidden to a child under pain of terible sanctions to be aware of what adults were doing to him. Thus when Freud discovered in the statements of his patients, the adverse effects the parents' behavior could have on the child, it was necessary for his self-protection to formulate a theory which would preserve discretion and in which all behavior seen as bad, culpable, and injust be attributed to the fantasy of the child, the parents only appearing as screens of projection for these fantasies. In C'est pour ton bien, Alice Miller explains:

... il aurait eu à subir de réelles vexations et se serait vu totalement isolé et rejeté par la société bourgeoise. . C'est cette omission qui permit à tant de spécialistes conditionnés par la pédagogie de se rallier à la théorie des instincts sans être forcés de remettre en question l'idéalisation de leurs parents. La théorie pulsionnelle et structurelle permettait de sauveguarder le commandement intériorisé dans la petite enfance: "Tu ne dois pas t'apercevoir de ce que te font les parents." (79)

In her studies of traditional education, Alice Miller discovered that:

... les parents luttent pour obtenir sur leurs enfants le pouvoir qu'ils ont dû eux-mêmes abdiquer auprès de leurs propres parents. La menace qu'ils ont senti peser sur eux dans les premières années de leur vie et dont ils ne peuvent se souvenir, ils la vivent pour la première fois avec leurs propres enfants, et c'est seulement alors, devant de plus faibles qu'eux, qu'ils se défendent souvent très puissamment. Ils s'appuient ce faisant sur une foule de rationalisations qui ont subsité jusqu'à aujourd'hui. (29) 
Thus, traditional education results in violence, be it against oneself (depression, neurosis, or suicide), be it against others (child abuse, violent crime or murder). Most children in Green's novels suffer from the consequences of such an education. For almost every punishment they receive, one can find counsel in old child-rearing manuals which prescribes such action. In Green's novels, we not only have descriptions of these traditional disciplines that Alice Miller calls "black pedagogy," we also see their repercussions on the lives of these characters who are plagued their entire lives with manifestations of neurosis and psychosis.

Alice Miller confesses that she sees her work as a mission, the goal of which is to convince the public that traditional pedagogy results in profound suffering for both children anc adults. She could very well use the families in Green's novels to illustrate her theories because through these characters, we can observe the disastrous effects of "black pedagogy." The theories of Ms. Miller become clearer and the consequences more tragic when one sees them unfold in the lives of those characters with whom we have come to identify.

It is uncommon for an author writing in the twenties and thirties to describe the mistreatment of children so frankly especially mistreatment that for generations has been seen as beneficial and "for the child's own good." At that time, it was revolutionary to recognize that a father or a mother could harm his or her children and if, by chance it should happen, one would have said that the parents had taken such measures because they loved their children and that 
they themselves had suffered as much as their sons and daughters in administering said punishments. Julien Green was not only one of the first to describe traditional education as abusive; he was one of the first in any field to recognize the parents as victims and to make a connection between their pain and the discipline they meted out to their children. He identifies these reservoirs of pain in parents such as Madame Grosgeorge in Leviathan:

Elle détesta l'enfant, fruit des violences qu'elle avait subies, depuis l'heure où elle le sentit se débattre dans ses entrailles, elle avait accompagné de sa haine les premières années de jeunesse, le châtiant avec un plaisir qui la vengeait des meurtrissures que sa naissance lui avait infligées. (745)

Mr. Green has always been a sharp observer of humanity; nevertheless, at the time he was writing most of his novels, the imperative that he preserve the ideal of the good mother and the noble father - the image of the happy family - at whatever price, would have served as a formidable obstacle to the truth. It is possible that the explanation of his ability to see beyond the cultural interdictions is to be found in his method of writing. He has often said that when he writes a novel, his words are to some degree dictated by his subconscious:

Il y a en moi, je le vois bien, quelqu'un que je ne connais pas, qui dicte des livres à celui qui les écrit et qui est moi-même. Cet autre moi ne peut s'exprimer que si je me mets à ma table pour écrire un roman. Qui est-ce? Est-ce aussi moi-même? Est-il responsable: Dois-je lui obeir? Est-il différent de l'homme que je connais, qui écrit ces livres que je vois dans la glace? Est-ce un moi plus profond qui fait partie du moi conscient? Est-ce un double? II sait des choses que je ne sais pas. (V: 566)

Green realizes that because his writing is dictated by his subconscious, 
he writes thoughts or ideas he otherwise would not consider prudent:

Sans l'écriture automatique qui force la main, la prudence de l'écrivain neutralise toutes les audaces. C'est l'étranger dont on ne sait pas le nom qui va trop loin et sauve la partie. (L'Expatrié 101)

It is well known that the subconscious is more clairvoyant than our conscious mind and that there are some actions that our subconscious has seen and understood that we can not explain. It is therefore probable that this phenomenon of the subconscious is responsible for the truth and the perspicacity which renders Green's descriptions of family life so familiar and painful. His novels reach memories or observations stored in the reader's mind which sometimes the latter has not here-to-fore been able to acknowledge.

In Green's novels, the parents are prisoners of their own educations which impel them to force their children to submit to their anger and their needs to control. The children, being objects of these parental needs, are actually prisoners without rights - the right to get angry, to have fear, to be sad, or above all, the right to express themselves liberally without fear of reprisal. In reading Green's novels, one becomes an uncomfortable witness to the tortuous unraveling of the lives of characters raised in such families - victims of an excessively strict education which results in obsessions, violence, extreme timidity, fear, fantasy, inferiority, and the need to control.

There have been others like Jean Pierre Piriou who have established a link between the literary creation of Julien Green and his life. Mr. Green himself declared: "Tout ce que j'écris procède en droite ligne de mon enfance" (IV: 
150). I propose in this thesis to extend the idea further by showing that the darkness and despair which strike us so profoundly in Green's novels can be traced not only to his childhood but likewise to the practice of traditional pedagogy as it is described in the works of Alice Miller, Katharina Rutschky, Erik Erickson, Scott Peck, John Bradshaw and others. In any discussion of traditional pedagogy, it is important to realize it is not the parents who are being condemned for they too are victims of this nefarious system of childrearing. In fact, most parents who use traditional pedagogy are sincerely trying to do what they believe is in the best interests of their child. The fault lies rather, with the system of early education rooted in religious beliefs which sees children as inherently bad, having been born in sin. Parents are assigned the sacred duty of breaking the willful spirits of the children by whatever means necessary. In Green's novels, we see the paralyzing effects of this form of discipline on the children who are experiencing it as well as on the adults who administer it. Even as they struggle with the painful effects of their own rigid upbringings (extreme timidity, shame, fear, lack of self-confidence, narcissism and violence), these individuals assiduously disperse the same poisonous pedagogy to the children now in their care. Thus the system is perpetuated generation after generation.

The details Mr. Green gives us concerning his characters' lives permit a direct link between their childhoods and the anguish they experience as adults. Equally important are the similarities between episodes in Green's childhood 
and those of the children in his novels. It is these parallels which enable me to propose that the tormented lives of Green's characters are the result of the author's early experiences with traditional pedagogy which shaped his ideas of child-parent relationships. For example, in Green's journal, one can read the following:

. . ma mère punissait mes soeurs avec une brosse à cheveux. Avant la correction, elle leur demandait: "Préfères-tu le côté plat ou le côté piquant?" (IV: 1202)

In Le Visionnaire, one can read:

Lorsqu'il s'agissait de peccadilles, elle se servait d'une simple brosse a cheveux pour me corriger; dans ces cas-là, j'avais le choix entre le plat de la brosse et les piquants. (210)

The demons with which the children and adults in Green's novels wrestle, are exactly what psychological research and studies would predict for individuals raised in the types of rigid authoritarian homes he describes. Whether intentional or not, Green's novels present a powerful indictment of traditional pedagogy. 


\section{CHAPTER ONE}

\section{TRADITIONAL PEDAGOGY AS SEEN IN GREEN'S LIFE AND FICTITIOUS CHARACTERS}

The term, traditional pedagogy, refers to the traditional child-rearing practices utilized by significant numbers of parents in most western societies. It is difficult to determine how far back in history, precepts of traditional pedagogy can be found, but it is likely that they had their roots very early in civilization when parents first felt a need to control their children. The principal justification for the attitudes and the actions of those who practice traditional pedagogy is the belief that the infant is born in sin - that he/she is bad. This leads to fear on the part of the parents. They are afraid that if they do not succeed in taming the child, his propensity for evil will grow and they, as his parents will be the first objects of his anger. Naturally, they must fight against such a possibility with whatever means possible. After all, it is for the good of the child. Almost every parent in Green's novels seems to be imbued with this belief and Bertrand Lombard in Varouna furnishes us with a sobering example:

A ces mots, Bertrand Lombard se leva. Dans sa colère il eut frappé sa fille, s'il avait pu la voir, car il se figurait qu'elle voulait lui tenir tête, alors que la pauvre enfant ne faisait que trembler de peur et répondait le plus doucement possible. (725)

Something inside Bertrand Lombard told him that he was mistaken in so far as 
the attitude of his daughter was concerned: "Sa conscience lui reprochait de traiter si rudement un être qui ne lui montrait jamais qu'une soumission exemplaire (731). But even then, he was incapable of treating Hélène differently so thoroughly had he been indoctrinated with the idea that children are naturally perverse and defiant. According to traditional pedagogy, it is acceptable for the parents to discharge their fury and rage freely on their children while the children are expected to completely control their emotions from a very young age - actually from the time they are born. In Epaves, the reader sees the child, Robert, battle to control his emotions while his aunt Elaine gives free rein to hers:

Et elle s'empara de son bras avec une feinte douceur pour l'entraîner vers la porte, mais Robert tenait toujours la main d'Henriette. D'une tape, Elaine fit lâcher prise à l'enfant qui éclata en sanglots. Pour cacher ses larmes il enfonçait deux poings rouges dans ses orbites. . . . Elle (Elaine) donna au petit garçon une vigoureuse poussée qui l'envoya presque dans les bras de son père: "Corrige-le donc!" cria-t-elle. (180)

The solution to the problem of the disobedient child is to make him totally submissive; such is the goal of this unhealthy method of child-rearing.

Achieving complete compliance from the child necessitates the destruction of his will or his power to choose his own actions. If a parent can destroy the child's will to the extent that the child's primary desire will be to do whatever the parent wants him to do, child-rearing becomes considerably less difficult. In the eighteenth century, parents had numerous books on the subject of training and discipline to which they could refer for direction. The following advice was 
given by J. Sulzer who was considered an expert on early childhood education:

II est tout naturel que l'esprit veuille suivre sa propre volonté, et si l'on ne s'y est pas pris correctement dans les deux premières années, on a du mal à atteindre son but par la suite. Ces premières années présentent en outre également l'avantage que l'on peut utiliser la force et la contrainte. Avec le temps, les enfants oublient tout ce qu'ils ont vécu dans la petite enfance. Si l'on parvient alors à leur ôter la volonté, par la suite ils ne se souviendront jamais d'en avoir eu une, et l'intensité des moyens que l'on aura dû mettre en oeuvre ne pourra donc pas avoir de conséquences néfastes. II faut donc dès le début, dès lors que les enfants sont capables de comprendre quelque chose, leur montrer aussi bien par la parole que par les actes qu'ils doivent se soumettre à la volonté des parents. (Miller, C'est pour ton bien 26)

According to Sulzer, the child's individuality must be extinguished early on before he is aware that his parents' wishes are not always the same as his own. Another common belief held that little children (one to two years old) purposely tried to manipulate their parents - that their tears were an effort to maneuver the adults. The early education experts of the day enthusiastically exhorted parents to battle these machinations on the part of their children with force. An additional example of what they were preaching can be found in another text for the education of children, Gedanken von der Erziehung der Kinder:

Si votre fils ne veut rien apprendre pour ne pas céder à ce que vous voudriez, s'il pleure intentionnellement pour vous braver, s'il fait du mal pour vous irriter, bref s'il fait sa petite tête:

Battez -le, faites le crier: Non, non, papa, non non!

Car une telle désobéissance équivaut à une déclaration de guerre contre votre personne. Votre fils veut vous prendre 
le pouvoir, et vous êtes en droit de combattre la force par la force... . Cette correction ne doit pas être purement mécanique mais le convaincre que vous êtes son maître. (Miller, C'est pour ton bien 29)

Monsieur Mesurat from Adrienne Mesurat is a powerful parent figure in Green's work who consistently employs the tactics advocated by traditional pedagogy. Convincing his child that he was master was evidently what Monsieur Mesurat was trying to accomplish when:

Il frappa sa poitrine à deux reprises. Et, brusquement il la gifla. Elle ne bougea pas. II vit sa joue blème se colorer un peu sous le coup. Ses yeux immobiles que l'horreur avait agrandis, ce regard de haine impuissante l'exciterent. II la gifla de nouveau de toutes ses forces. Elle chancela et poussa un soupir qui ressemblait à un râle. (390)

Having been conditioned from a very early age that disobedience has terrifying consequences, an individual will have a difficult time ever asserting himself. Even as an adult, he will find that he always cedes to the wishes of others.

Green gives us few details in his Journal as far as discipline in his family was concerned; consequently, we do not know by what methods his parents achieved the destruction of his will - but of their success there can be little doubt. In Mille chemins ouverts, the author remembers:

Quand mon père revint du Danemark, ... il m'annonça qu'il avait reçu une lettre de mon oncle Walter à mon sujet ... que l'oncle Walter offrait de se charger de moi pendant quatre ans si je désirais finir mes études dans une université américaine. Je ne voulais à aucun prix quitter la France, que j'aimais, pour un pays que je ne connaissais pas. De plus, je me considérais comme Français, mais le 
moyen de désobéir à mon père? Cela, je n'y aurais pas songé une minute. II m'aurait envoyé à Tombouctou que j'aurais dit amen. Je n'exprimai donc aucune opinion et dis simplement: All right, comme toujours. Je me félicite aujourd'hui, non seulement de lui avoir toujours obéi tout de suite et sans jamais discuter, mais de n'avoir pas fait de difficultés. . . Affreusement éberlué, je murmurai: All right, puis j'allai aussitôt faire part de l'épouvantable nouvelle à mon ami Paul . . .II m'écouta, puis dit avec force: "Il faut te révolter." Me révolter contre papa! Je lui dis que ce n'était pas possible et il me couvrit d'un regard de mépris." (10181019)

The inability to say "no" does not only manifest itself in parent-child relationships, for when one is so conditioned, one will have difficulty saying "no" to anyone. The important thing will not be what one thinks or wants or even what is right. The important thing will be never to cause any difficulties. Julien Green recounts an experience that he had in the army:

Une autre fois, il fut décidé que nous irions tous à Neunkirchen pour voir les hauts fourneaux. Je n'avais aucune envie de voir les hauts fourneaux, mais je dis oui, parce que je disais presque toujours oui quand je pensais que cela pouvait faire plaisir. (V: 989)

Accounts of similar reactions are found in Green's autobiography, Jeunesse:

“Comment avais-je pu dire oui si vite? Mais je disais toujours oui, et puis comment dire non?" (1433). Farther on, he adds: "J'obeis parce que j'obéissais toujours" (1437).

It should not be surprising then to find that many of Green's characters are also afflicted with a need to obey almost anyone especially if he speaks to them with authority. Angèle in Léviathan recognized that she gave in to others 
in part so they would not be angry with her. If the parent who punishes the child for daring to disobey, fully uses his advantages of size, voice, eyes and power to inflict pain, the child who is totally dependant on him emotionally and physically will be traumatized to the extent that he will, as the experts said, present no more problems. The original trauma may be forgotten, but it will live on in the subconscious regulating his behavior forever. This is poignantly illustrated by the description of Angèie in Léviathan:

Seulement elle avait été faible bien des fois; elle avait cédé à beaucoup de personnes ... parce que c'était à ce prix seul qu'on était aimable avec elle. (651)

Philippe in Epaves admits:

Je ne sais pas résister aux gens qui viennent me demander de l'argent. (167-168)

$\mathrm{He}$ is unable to say "no". Elaine has the same problem; she can not refuse a request. When Henriette begs her to get some money from Philippe for her lover, Elaine, being incapable of denying her sister's request, asks for the money on the pretext that she herself needs it. In Le Malfaiteur, Jean, speaking of his former tutor, Monsieur Paris, says:

Enfin il me toucha la main et me fit signe de le suivre. Je ne songeai pas à résister: il avait encore à mes yeux l'ascendant du professeur et lui désobéir me paraissait impossible. (301)

This reaction occurs many years after Monsieur Paris had been driven out of town by Jean's father. Jean notes:

C'était la première fois de ma vie qu'un de mes aînés 
sollicitait une faveur de ma part, et je n'eus garde de la refuser. (304)

It is easy to see why over the years inculcating children with a profound respect for their parents, their elders and those in authority has seemed so desirable. The success of such training, albeit cruel, certainly eliminates a lot of difficulties in the early years. Unfortunately, as we see so clearly illustrated in Green's novels, the problems which result from such submission are disastrous. Persons raised in this manner will likely be forever crippled emotionally; they will become victims of others or they will become abusers. In either case, they are doomed to spend their lives trying to deal with psychological scars of which they are unaware.

Parents or caregivers seeking to destroy the child's will have some powerful techniques at their disposal which have been perfected through the generations. These methods are clearly described in some of the child-rearing manuals but are often not formally taught; rather they are simply absorbed by one generation and passed on to the next. Indeed, scores of parents use them not realizing what they do. Many others consciously cultivate and perfect them, believing in all sincerity that it is for the best of their children that they do so. These are the devastating powers of the parental voice, the parental look and corporal punishment.

Thus, the adult must instill obedience by the exercise of his power; this is done with a severe glance, a firm word, possibly by means of physical force. (qtd. in Miller, For Your Own Good 29) 
About the time of Julien Green's birth, A. Matthias wrote a popular child-rearing manual. He advised parents:

A very fine and worthy position is assumed by silent punishment or silent reproof, which expresses itself by a look .... Silence often has more force than many words and the eye more force than the mouth. It has been correctly pointed out that man uses his gaze to tame wild beasts; should it not therefore by easy for him to restrain all the bad and perverse instincts and impulses of a young mind? If we have nurtured and properly trained our children's sensitivity from the beginning, then a single glance will have more effect than a cane or switch.... "The eye discerns, the heart burns" should be our preferred motto in punishing. (qtd. in Miller, For Your Own Good 3738)

In the mid-nineteenth century, a man named Schreber also wrote a series of books on child-rearing. They were so popular that they went through forty printings and were translated into several languages. He counseled:

The little ones' displays of temper as indicated by screaming or crying without cause should be regarded as the first test of your spiritual and pedagogical principles. Now you should proceed. . . by quickly diverting its attention, by stern words, threatening gestures, rapping on the bed ... or if none of this helps, by appropriately mild corporal admonitions repeated persistently at brief intervals until the child quiets down or falls asleep. . . This procedure will be necessary only once or at most twice, and then you will be master of the child forever. From now on, a glance, a word or a single threatening gesture will be sufficient to control the child. (qtd. in Miller, For Your Own Good 5)

Dr. Schreber goes on to say that if parents are consistent in this, they will soon be rewarded by the emergence of that desirable situation in which the child will be controlled almost entirely by a parental glance alone. 
Mr. Green was familiar with the force of "the look" which was used on him by members of his family. In Partir avant le jour, he wrote: "Je me sentis blêmir sous le féroce oeil bleu de mon beau-frère" (779). In Memories of Happy Days. the author remernbers:

Our whispering annoyed our father who glared at us as savagely as he could, thus striking terror in my soul ... I alone remained steeped in horrible gloom and felt like a man about to be guillotined. $(69-70)$

The mother of Marie Therèse in Le Visionnaire, used the parental look so often that her daugher could not look her in the eyes. Marie-Therèse says of her mother:

... il me semble que je n'ai jamais considéré ma mère en face, tant elle m'en imposait; aussi comment parler d'un regard que je n'étais pas capable de soutenir? Chaque fois qu'il rencontrait le mien, j'en reculais de frayeur. (210)

Such is the force of Uncle Firmin's regard that Camille remarks:

Mon oncle ... je crois que si vous pouviez me tuer d'un coup d'oeil, je serais mort. (II: 1009)

The novel, Varouna gives us many examples of the unnerving parental look:

Hélène s'était dirigée vers son père qui se tenait debout dans l'embrasure d'une fenêtre, mais il l'accueillit d'un regard si singulier qu'elle pensa lui avoir déplu. Et tout à coup, dans cette salle pleine de monde, elle éprouva le sentiment d'une grande solitude. (719)

In Léviathan, when the high-handed Madame Londe tries to get Angèle to admit that she was with Gueret when attacked, the author describes the older woman's use of "the look" to force Angèle's confession: 
Elle (Madame Londe) réfléchit quelques secondes; son oeil brillant semblait chercher la méchanceté qui ferait le plus de mal. (705-706)

Alice Miller, realizing that some readers would minimalize the effects such

actions can have on children wrote in 1983:

Je voulais à tout prix montrer que les regards d'interdiction ou de mépris que percevait le nourrisson pouvaient entraîner à l'âge adulte de graves troubles, en particulier des perversions et des névroses obsessionnelles. (Cest pour ton bien 18)

In addition to "the look," parents have at their disposal another very effective tool as they strive to cultivate submissiveness in their children. It is the voice. A. Matthias, whom we have previously mentioned, discusses the power of the voice at length in his child-rearing manual:

C'est le ton qui fait la musique, and this applies to pedagogy as well. Anyone fortunate enough to possess a voice whose tone can convey the most diverse moods and emotions has received from Mother Nature a fortuitous means of meting out punishment. (qtd. in Miller, For Your Own Good 38)

Others have recognized the perverse powers of the voice. In the novel, The Heart of Darkness by Joseph Conrad, "Mistah" Kurz is the portrait of an adventurer who devotes himself to evil in the depths of the Congo and who makes a population of slaves cower before him by the power of his voice alone. His goal was not too different from the goals of many parents - control. Manuel in Le Visionnaire, reports that: "Je leur criais des recommandations d'une voix nasale qui les faisait rire. J'imitais le ton des parents" (294). Those who as 
children have been conditioned to fear the parental tone of voice will not only be controlled for the rest of their lives by those who use it, but in an ironic twist, they will also be controlled by those who use a soft, accommodating tone of voice. In Partir avant le jour. Julien Green wrote:

... il se mit à me parler d'une voix si douce que tout l'éloignement que je pouvais avoir pour lui se changea en affection. Je ne puis dire cela autrement. Un élan me portait vers ceux qui me parlaient ainsi. (770)

In fact, those raised to fear the parental tone of voice will not even notice if their interlocutor is attacking them, discrediting them etc. as long as he speaks in an aimiable fashion: "Mr. Knight lui dit d'une voix plus courtoise que ne l'étaient ses paroles" (III: 48).

As effective as the parental tone and parental look are, the most popular and cruelest method used to destroy the will of a child is corporal punishment. In the Encyclopedia of Pedagogy K. G. Hergang, highly recommends it to parents:

With the most forceful form of punishment, corporal chastisement, we come to the ultimate in punishment ... What can be more obvious than the rule, "He who won't hear must be made to feel?" (qtd. in Miller, For Your Own Good 44)

Jean, Le Visionnaire, remembers when Marie Therèse's mother:

... secoua si rudement sa fille qu'elle lui arracha un cri et le visage de Marie-Thérèse m'apparut un court instant; je me souviens qu'elle fermait les yeux, et qu'une mèche de ses cheveux noirs collés par les larmes lui barrait la joue. La violence de cette scène me rendait malade. . . (267) 
Corporal punishment can be administered in different ways. Washing out someone's mouth was a common practice in previous generations. Marie Thérèse gives us an idea of the humiliation and disgust she experienced as her mother administered this punishment:

Un mensonge recevait le symbolique châtiment du savon noir: cette matière acre et gluante ma mère m'en emplissait la bouche, promenant ensuite deux doigts dans mon palais et sur ma langue pour me laver de mes fausses paroles. (224)

Green himself was familiar with this practice even though he apparently never had to experience it directly. He writes:

“Ne mens jamais. Mentir est un péché d'esclave." . . Elle (sa mère) savait que je ne mentais jamais. Mais it n'en allait pas tout à fait de même avec certaines de mes soeurs. Quand l'une de celles-là était prise en flagrant délit de contre-vérité, elle se voyait laver l'intérieur de la bouche avec du savon noir. (VI: 899)

Whatever his personal experience may have been, Julien Green depicts most of the parents in his novels as freely and self-righteously administering physical punishments. Madame Grosgeorge provides a good example of this type of behavior. She is a tormented and violent woman. Unfortunately it is her son Andre, who is most often the object of her fury.

André, fit Mme. Grosgeorge, je vous préviens que ce vacarme vous vaudra une gifle. (l: 614)

Hélène in Varouna knew that:

. . si elle ne revenait pas avant le coucher du soleil, une taloche l'attendait de la main de sa tante Marguerite, qui la guettait au bas du jardin. (689) 
Her aunt Marguerite was not contented to administer physical punishment herself, she also threatened Hélène with the possibility of severe chastisement from her father:

Patience, vilaine, tu vas tâter du fouet, ou je connais bien mal ton pere. (766)

Physical abuse was such a part of Hélène's life that not only did she accept it as normal, she thought her elders were justified in their actions. She actually believed her behavior merited such treatment: "Et je me demande à quoi servent les oreilles de femmes, si ce n'est qu'on saisit par là les récalcitrantes" (771). Sometimes Green meticulously describes the barbaric cruelty of corporal punishment as in the case of Madame Grosgeorge and her son, André:

. . . en disant ces mots elle serra un peu les dents et planta ses yeux dans ceux de son fils. Puis, les coudes au corps, elle leva l'avant-bras droit, le rejetant en arrière aussi loin qu'il lui était possible. Dans cette position elle demeura une seconde sans qu'un muscle de son corps bronchât et, tout à coup, après s'être insensiblement tournée vers la droite, comme pour prendre un peu d'élan, elle frappa l'enfant au visage avec la force et la brutalité d'une machine. (I: 616)

Other times, there is only a passing reference to the violence such as is found in the description of Uncle Firmin's sister:

En la voyant aller et venir au milieu d'eux, on avait l'impression que les gifles tombaient d'elle comme les poires mûres d'un poirier dans une tempête. Elle passait, semblait-il dans un perpétuel fracas de taloches. (II: 970)

Anne Green, Julien Green's sister describes their mother, Mary Green: 
. . une femme étant l'objet de fréquentes sautes

d'humeur, une femme que la présence des enfants énerve très vite et qui, à l'occasion, ne se privait pas pour leur administrer quelques fessées. (qtd. in Piriou 57)

Julien, however, only remembers his mother having struck him but one time.

She had asked him how one said, "blackbird" in French and when he answered, "merle," he received "une gifle magistrale" (IV: 226). Instead of becoming angry or hurt, Green says that he felt such humiliation for his mother that he didn't even try to explain the error to her saying that he prefered to keep silent so as not to embarrass her. Not only was his legitimate anger suppressed, his fear of being disrespectful in regards to his mother was so strong that he projected what he felt - humiliation - onto her.

It should not be surprising that a man born in 1902 and raised in an educated family where the parents were trying their best to do right by their children would see corporal punishment as a part of family life. It seems that most, if not all of the books written on the subject of child-rearing during the last half of the nineteenth century, strongly advocated its practice. One such text explains to parents how valuable it can be:

Pour certaines fautes, celui-ci (châtiment corporel) constitue en effet la punition adéquate: il humilie et frappe, prouve concrètement la nécessité de se plier à un ordre supérieur et laisse en même temps transparaître toute l'énergie de l'amour paternel. (qtd. in Miller, C'est pour ton bien 63)

As with all the other exhortations to parents from this time period, this one stresses the absolutely irrefutable need for the child to be so humiliated and 
spiritually broken that he will bend to his parents' every wish. At the same time, his love, devotion and respect for them should grow. The intimidation must be forceful enough to preclude the possibility that the child will ever dare admit his parents are anything other than perfect.

The least visible means of controlling a child but certainly no less nefarious is manipulation. Because the child cannot see through the subterfuge, it is difficult for him to comprehend this kind of abuse. Unbelievable as it may seem, child-rearing texts of the previous two centuries contain detailed examples of how one can use manipulation to achieve control. It was justified because those who used it were ostensibly doing so for a noble purpose - to save the child's soul. Uncle Firmin in Si i'étais vous seems to have perfectly mastered this method. He is particulary malicious because he uses religion to lend authority to his deeds - always presenting himself as pious, self-sacrificing, filled with love for the children in his care and imparting to his decisions, no matter how cruel, divine sanction by declaring that he has been "inspired." When his nephew André gets some bad marks at college, Uncle Firmin uses the event as a pretext to do what he had been wanting to do all along - remove André from college and send him to learn a trade:

Inspiré oui, Mais nous parlions d'André. Je le retire du collège. C'est décidé. Et je le mets chez $\mathrm{M}$. Ballivon, mon vieil ami, un digne homme, M. Ballivon achèvera l'éducation d'André, comprends-tu? II lui apprendra un métier, un métier superbe: le drap. André apprendra à vendre du drap. Et il aimera le drap. C'est là du solide, Elise. Mon aỉeul signa d'une croix. Et je n'en ai pas honte . ... En décidant de retirer André du collège, j'ai agi par 
inspiration. (967)

Uncle Firmin's hypocrisy is evident later when he gushes to Andre:

Cher André a qui je pardonne sa très vilaine conduite de grand coeur, oh! de grand coeur! Je lui pardonne oui. (968)

He pardons André but he withdraws him from college nevertheless! The most chilling example of this man's manipulation is to be found in the matter of Stéphanie and Camille's marriage. When Stéphanie tells him that she is in love with the son of M. Goutte, Uncle Firmin tells her that he will pray for her. A few days later, after complaining of not being able to get along with Camilie, Stéphanie again speaks to her uncle about the son of $M$. Goutte and requests that Firmin speak to $M$. Goutte on her behalf:

II s'agita un peu dans son fauteuil, poussa de grands soupirs et se cacha le visage dans les mains pendant quelques secondes, puis se levant d'un air accablé, il secoua la tête et dit: "Je verrai, mon enfant, je prendrai conseil." . . et il se retira dans sa chambre, bouleversé d'orgueil à l'idée de ce bonheur qu'il pouvait faire ou détruire. . . Il avait près de soixante-dix ans quand il décida que Stephanie épouserait Camille, union qui lui paraissait d'autant plus désirable qu'elle ne semblait devoir plaire ni à l'un ni à l'autre des intéressés, mais il avait eu plusieurs inspirations sur ce point et se montra vite intraitable. (972973)

However, when Camille learned of Uncle Firmin's decision:

il se montrait d'une docilité qui . . . déçut si fort oncle Firmin que le mariage faillit ne point se faire, car il eût fallu que cette union déplut à tout le monde pour offrir aux yeux du vieillard les marques de la perfection. (973)

Later, the author reveals that Uncle Firmin: 
avait voulu le mariage de Stéphanie pour toutes sortes de raisons dont l'une était la manière dont Elise regardait Camille ... .A sa façon, il l'aimait (Elise) mais il ne l'aimait que malheureuse. (974)

In reality, Uncle Firmin is a coward who cannot take responsibility for his actions. Inspiration serves him well in this matter by relieving him of any accountability:

... j'ai eu, oui, une inspiration. J'ai obéi comme à un ordre. Exactement. C'est cela: j'obéis à un ordre. Je me laisse conduire, comprends - tu?" (968)

Uncle Firmin is not alone among Green's characters in so far as manipulation is concerned. Parents or caretakers who coldly manipulate the children in their care abound: Madame Londe / Angèle, Mrs. Fletcher / Emily and Madame Plasse / Marie Thérèse - to name a few, but perhaps Marie, from the novel Minuit is the most thoroughly evil of them all. Her monstrously cruel words are directly responsible for driving her younger cousin to such despair that she takes her own life. In this case, the parent or guardian is not only responsible for killing the child's soul, but for her actual physical death:

"Marie, dit-elle avec effort, je sais que je ne te vaux pas. Tu es beaucoup plus intelligente, beaucoup plus forte. . .Je veux le revoir, une dernière fois. II le faut, ajouta-t-elle mollement.

Tu n'es pas folle?. . il est trop tard." La jeune femme abaissa vers elle un regard défait, mendiant la permission qu'on lui refusait. . . "J'aurais couru. . .

Blanche, j'ai sacrifié une heure de mon temps pour t'accompagner jusqu'ici. Est-il juste qu'a présent tu reviennes sur ta promesse de m'obéir?" 
Sous le bord du chapeau, les grands yeux tragiques de Blanche essayèrent de comprendre ce raisonnement. "Vois-tu poursuivit Marie de sa voix précise qui détachait les mots et leur prêtait un sens irréfutable, il y a dans le monde des milliers de femmes comme toi. Vous n'êtes pas de celles qui retiennent les hommes. Il vous manque. . .quelque chose.". . .

il m'a juré d'agiter son mouchoir même s'il ne m'apercevait pas sur la colline.

Hum! Enfin! La vie t'apprendra de dures leçons, Blanche. Tu as encore cinq minutes. Je vais aller t'attendre dans la voiture; je vous laisse seuls." (399)

Marie is far from feeling any remorse for the way she has spoken to Blanche and the pain her words may have inflicted. Her only sentiments are those of pride:

En prononçant ces derniers mots, elle eut un sourire mystérieux qui approuvait le tact et l'esprit dont elle faisait preuve, mais elle regretta aussi qu'une personne plus instruite que sa cousine ne fût pas là pour goûter la finesse de ce qu'elle venait de dire. Et elle appliqua une petite tape indulgente sur la main de Blanche, puis regagna le sentier.

La jeune femme la vit descendre à travers les champs, d'un pas sautillant qui lui donnait l'allure d'une fillette à cheveux gris, et elle compara cette insouciance à la tristesse qui ravageait son propre coeur. (399-400)

The train appears at the bottom of the hill but not a single passenger waves a handkerchief even though Blanche waves hers desperately. Like many of Green's characters who are so severely lacking in self-esteem, Blanche feels her only chance for happiness lies with this man and now his rejection seems to confirm all her aunt's words. It is too much. Feeling worthless and devoid of any hope, she ends her life. 
Manipulation is devastating to the child because it is so difficult for him to realize that he is being abused. If it should so happen that he would possibly feel any resentment or anger toward his abuser, he would most certainly feel guilty. All of the methods advocated by traditional pedagogy, the look, the tone of voice, manipulation, and corporal punishment, contribute to the despair and darkness found in Green's novels. These tactics are not only unhealthy and completely self-serving, they are evil. They are evil because their goal is the destruction of the child's emotions and his will, while acquiring complete control of his life. It is in fact the murder of the child's soul. This is one of the unforgettable aspects of Green's novels - A majority of his characters seem to have lost their souls. 


\section{CHAPTER TWO}

\section{THE ROLE OF RELIGION IN THE CREATION \\ OF THE FAMILY PRISON}

The fourth commandment states: "Thou shalt honor thy father and thy mother." Indirectly linking parents and God justifies the mistreatment of children by their mothers and/or fathers because it sanctions compeling children of fanatically religious authoritarian parents to love and respect their parents no matter how much pain and suffering the latter inflict upon them. Few ever realize as did Adrienne Mesurat that, "la crainte seule formait le fond de son respect, et . . l'amour filial n'y jouait aucun rôle" (I: 346). Most children of fanatically religious parents feel as did Jean in Le malfaiteur, who was confused by his father and struggled with his feelings for him. In his confession, he wrote:

... je m'assis au bord d'une chaise en considérant d'un oeil inquiet cet homme qui passait pour bon et qui pourtant me faisait peur. ... J'étais troublé avant que mon père ouvrit la bouche et me comportai déjà en coupable, bien qu'on ne m'eût encore accusé de rien. (288)

Jean has been taught that his father is good, but his instincts and past experiences tell him otherwise. Nevertheless, he cannot admit that his father is bad - actually evil. To do so would be a terrible sin. It would be breaking the fourth commandment of the Old Testament. Instead Jean denies his feelings of repulsion and disgust, interpreting them as feelings of embarrassment for his 
father: ". . j'avais honte de mon père et de sa curiosité" (288). Later, he explains to Hedwidge why he did not defend M. Paris: ". . la colère des "justes" est un spectacle intimidant et je tremblais devant mon père. Sa vertu m'épouvantait" (290). Again, Jean denies the truth. It was his father's anger, his cruelty, his maliciousness that frightened his son, but Jean cannot admit that, so he says it was his father's virtue. Likewise indoctrinated with the idea of parents' infallibility, Marie Therèse could never suspect that her mother did not dearly cherish her:

L'esprit imbu de toutes les idées courantes sur l'amour maternel, je n'imaginais pas que maman pût ne pas me chérir; je la croyais d'une sévérité excessive, mais mon audace n'allait pas plus loin, je ne comprenais pas qu'en semblant me reprocher de petits méfaits insignifiants, c'était à mon être, à mon existence même qu'elle en voulait. (II: 232)

Expecting a child to believe his parents are faultless requires him to mistrust his senses. He cannot see what he sees, hear what he hears, or feel what he feels. All this at the very time in his life when he should be learning how to pay attention to these senses and to use them efficiently. It is no wonder that such children having learned to mistrust their senses, have little or no self-confidence when they reach adulthood.

The biblical quotation, "For whom the Lord loveth, he correcteth" (King James Bible, Prov. 3:12), implies that the adult shares in the divine omnipotence and one can indeed interpret it to mean that punishing a child is essential to good parenting. Throughout history, a lot of evil has been foisted 
on the world in the name of religion and no small portion of it has been aimed at children; who according to most western religions, are born in sin and are therefore to be treated as sinners. It is the responsibility of parents to correct their nature by whatever means are necessary. In Proverbs 23:13-14, one can read: "Withhold not correction from the child; for if thou beatest him with the rod, he shall not die. Thou shalt beat him with the rod, and shall deliver his soul from hell." The child is expected to be grateful for the good intentions of his parents, to close his eyes to the cruelty of their actions, to accept their ideas and finally, he must give them no difficulty in so far as what they expect of him. In Minuit, the mother of Monsieur Edme taunts Elisabeth: "Mon fils vous apprendra à me respecter" (507). What she actually means is that her son will teach Elisabeth to "obey " her. In traditional pedagogy, the word "respect" is an euphemism for "obey".

In order for parents to teach the child these almost universal values, they believe that they are justified - doing their God-given duty - when they resort to lies, deception, cruelty, humiliation or even physical abuse. The adults do not perceive their actions as being wrong; they are using them solely for the purpose of attaining a sacred goal: assuring that their children will not be liars, deceptive, cruel and egotistical (Miller, For Your Own Good 64). The obvious advantage of linking absolute respect for parents to religion is to lead the child to believe that disobeying parents is equivalent to disobeying God - a very serious transgression indeed. Marie Therèse had been taught this principle 
well:

Je désobéissais non seulement à ma mère, mais aux religieuses, mon confesseur et à Dieu. (II: 238)

Alice Miller explains the advantage of linking obedience to parents with obedience to God:

La comparaison avec Dieu donne le sentiment de toute puissance: de même que celui qui a véritablement la foi n'attend pas de Dieu qu'il lui donne d'explications (cf. le livre de la Genèse) l'enfant doit se soumettre à l'adulte sans demander de raisons. (C'est pour ton bien 55)

If the children in Uncle Firmin's care give him any trouble, he intimidates them with this idea:

Tu n'es pas fou? fit le vieillard d'une voix tout à coup éclatante. Tu me braves! Sous mon toit ... Tu n'as pas peur de Dieu?" (II: 1005)

Dr. Susan Forward, an internationally recognized therapist and author who has researched the beliefs that contribute to the mistreatment of children by their parents, writes:

Our culture and our religions are almost unanimous in upholding the omnipotence of parental authority. It's acceptable to express anger at our husbands, wives, lovers, siblings, bosses and friends, but it's almost taboo to assertively confront our parents. ... The Judeo-Christian tradition enshrines the taboo in our collective unconscious by pronouncing "God the Father" and directing us to "Honor thy father and mother". . . According to the conventional wisdom, our parents are empowered to control us simply because they gave us life. (15-16)

Training that obliges children to see their parents as faultless forces them to rationalize that since their parents are always right, they themselves must be 
flawed. Backed up by the teachings of their religion, parents can impose all sorts of interdictions on their children's actions with a clear conscience. They can manipulate them and physically abuse them, all the while claiming that they are only carrying out the demands of their sacred trust - to save the child from evil. What such parents do not realize is that it is their actions that are evil - not the child's. Dr. M. Scott Peck in his book, People of the Lie, observes:

Strangely enough, evil people are often destructive because they are attempting to destroy evil. The problem is that they misplace the locus of the evil. Instead of destroying others they should be destroying the sickness within themselves. As life often threatens their self-image of perfection, they are often busily engaged in hating and destroying that life usually in the name of righteousness. (106)

This would explain why some parents are uncomfortable if their children are not suffering as much as they did, or if they suspect the children are enjoying themselves. Marie Thérèse recognized this in her mother when she said that:

Ma mère ne se doutait pas que cette partie du paysage nous intéressait au point de nous faire battre le coeur, autrement elle eût changé l'itinéraire de notre promenade; tout plaisir, en effet, lui paraissait suspect ... (II: 206)

Farther on Dr. Peck elaborates on the idea of evil being involved in the mistreatment of children:

For the evil to so misuse their power, they must have the power to use it in the first place. They must have some kind of dominion over their victims. The most common relationship of dominion is that of parent over child. Children are weak, defenseless, and trapped in relation to their parents. ... It is no wonder, then, that the majority of the victims of evil are children. (107) 
Religion not only reinforces the parents' authority; it has traditionally exhorted them to agressively annihilate any signs of emotions in their children especially any having to do with anger or sex. Children are not to be sad because that would be ingratitude. They can not be frustrated because they must learn patience. They can not grieve because that would indicate they are too self-absorbed. They are not even allowed to be too happy because there is so much suffering in the world. Uncle Firmin is a good example of this point of view. His thoughts as far as Stéphanie (his niece for whom he was responsible) was concerned were: “. . . il l'eût voulue pour le bien de son âme, moins belle et moins heureuse" (II: 972).

In this system of education, repressing all emotions is seen as desirable, because it represents strength and control. Julien Green seemed to be embracing this philosophy when he wrote in his journal:

Quand je regarde les personnes avec qui je vis, il me paraît évident qu'elles se dominent très bien. Mais ce que j'ai en moi ne se laisse pas dominer. (IV: 26)

A college textbook printed as late as 1931 propagates the pernicious myth that:

There is need for control of emotions. Emotions when given full expression will burn themselves out; if given no expression, they often die of starvation. . It is pleasing to hear the well-bred person, the person who has perfect control of himself at all times. (qtd. in Ralston 66)

The problem with following such advice is that in order to do so, one has to be less than honest. He has to learn to hide what he really feels or thinks and 
pretend to espouse whatever is acceptable. To be forced to bury natural healthy emotions creates a multitude of problems, but one of the most tragic results is that the child so disciplined steadily loses confidence in himself, eventually becoming emotionally crippled. When a child is punished for getting angry, he doesn't know that anger is a basic healthy emotion which everyone feels. Because the child believes that his parents or guardians are always right, he not only thinks that he is bad because he feels this way, but he thinks no one else has ever experienced the same feelings. He is therefore certain that something is wrong with him - that it is he who is flawed in some way. If his thoughts and emotions are bad, he must be deficient himself, or so goes his reasoning. He will, in all likelihood, never be able to trust his own perceptions of anything or be able to stand up for anything if challenged. He will forever be afraid. John Bradshaw explains:

Without our emotions we can't know where we are with our basic needs. Without our basic needs we cannot live as functional human beings. To deny our emotions is to deny the ground and vital energy of our life. (The Family 145)

Another aspect of parental abuse has to do with the sin of pride. According to most Christians, it is one of the greatest sins. In order to assure that their children will never be afflicted with this dreaded characteristic, parents seek ways to prevent its growth. Unfortunately, they usually confuse pride with healthy self-esteem and it is the self-esteem that is destroyed. As they energetically endeavor to eradicate anything that could make the child feel good about himself, compliments are rare and negative remarks are excessive. 
On one occasion, Julien Green's mother, speaking of her late brother, said to Julien: "Il était plus beau que toi" (V: 787). Years later the author wrote:

Quand je dis que les paroles de ma mère furent vite effacées par la joie de vivre, je dis mal, car il y en eut une que je retins, je l'avoue à ma confusion: "ton oncle Willie était plus beau que toi." Plus beau que moi! (V: 788)

The young Julien had a similar experience with his brother-in-law, a man much older than Julien, who once told him: "Tu es peut-être le garçon le plus laid qu'il m'ait jamais été donné de voir" (V: 785). These comments deeply wounded Green and would never be forgotten. Years later in his autobiography, we can see his efforts to come to some kind of peace concerning them. He wrote:

Il me fallut de longues années pour comprendre qu'il (son beau-frère) avait dit ces mots pour me préserver, espérait-il, d'une vanité qui ne me menaçait en rien à cette époque, car je n'avais alors aucune opinion sur mon visage, mais la phrase inhumaine me travailla et me rendit plus timide encore que je ne l'étais de nature. (V: 785)

Later in Terre lointaine, Green again mentioned this devastating experience:

La phrase meurtrière que j'avais entendue jadis sur les lèvres de mon beau-frère me revenait quelquefois tuant l'espoir. Cet homme m'avait dit que j'étais laid et je ne voulais pas le croire mais l'idée s'était logée dans ma tête pour de longues années que personne ne m'aimerait jamais. (1093)

Jean in Le Malfaiteur was similarly haunted by words spoken by his father forty years earlier expressing fear that his son was going to "finir en correctionelle" and that he would be "la honte de [sa] famille" (281). 
Adults often say dreadful things to children such as they would never consider saying to another adult. They feel justified in so doing because they believe it is for the "child's own good." The use of this technique is not limited to the eradication of any beginnings of pride; it is also used to prevent the child from sinning in other ways. Sometimes the object is to so terrorize the child that he will never dare to do anything he has been warned against. In fact, the fanaticism of some religious parents leads them to say absolutely fearful things to their children which may haunt them into adulthood, if not their entire lives. Julien Green's mother often reminded him: “Souviens-toi que Dieu te regarde sans cesse." The damage of such a remark varies with the image the child has of God. At the least, it is disquieting to believe that one is the object of constant surveillance, but if the child has learned to think of God as He is portrayed in the Old Testament - a God of wrath, someone to be feared - the result can be paranoia and certain inhibition.

Another frightfully controlling method used by parents, ostensibly to impress upon the child the seriousness of a certain action, is to declare that it would be better for the child to die than to fall into such temptation. Mr. Green's mother reportedly instructed him: ". . .si tu devais commettre une mauvaise action, j'aimerais mieux te voir mort, comprends-tu? Mort à mes pieds" ( $V: 689$ ). We find a similar exhortation in Les pays lointains, when Mrs. Escridge tells her daughter, Elizabeth: "Je veux dire que, plutôt que de te savoir catholique, j'aimerais mieux te voir morte, là, morte à mes pieds" (90). Such sentiments are 
to be found as far back as the Middle Ages. In medieval times, the death of the body was less important than the death of the soul. Joinville, a famous French historian and biographer of Saint Louis relates the words of the very pious and very strict Blanche de Castille, the authoritarian mother of the king, in those terms: "J'aimerais mieux voir mon fils mort que de lui voir commettre un seul péché mortel" (qtd. in Pernound 193).

In Le Voyageur sur la terre, the author has given us a sobering example of a parent (or in this case, the aunt who was raising Daniel O'Donovan) using fear to impose her will on the child. Daniel's aunt would frequently recount terrifying stories in which "Il s'y mêlait beaucoup de sorcellerie et beaucoup de piéte" and which Daniel remembered, "me remplissaient de crainte et me donnaient de mauvais rêves" (23). One of the most terrifying was the story of Frank Mac Kenna:

Frank Mac Kenna voulut à toute force chasser le lière un dimanche matin. Son père le lui défendit, puis, comme il persistait dans son dessein, il le maudit d'une manière effroyable: "Fasse le Ciel que tu ne reviennes pas en vie chez nous, si tu vas à la chasse le jour du Seigneur." Mais Frank ne l'écouta pas et il partit avec ses compagnons ... et vers le soir tous les jeunes gens abandonnèrent la chasse et retournèrent chez eux, à l'exception de Frank Mac Kenna. .. et on le retrouvait toujours couché par terre dans la montagne ... Et ma tante ajoutait qu'il avait son chapeau rabattu sur les yeux et son livre de messe ouvert et posé sur sa bouche. Ainsi les paroles du père avaient été entendues. (I: 24)

The use of religion to legitimize and give divine sanction to their words and actions, parents or other adults can not only control children; they can wreck 
havoc with their emotional lives. When Julien Green changed his mind concerning a religious life, he received a letter from Père $X$ :

Fut-ce à ce moment là ou plus tard, ou plus tôt qu'il me donna à entendre qu'il n'était pas sûr de mon salut? Cette parole tomba en moi comme une pierre dans un abîme. J'ai passé une partie de ma vie à écarter de mon âme les pensées effrayantes qui furent le résultat de cette opinion. Loin de moi la tentation de juger un homme qui m'était bien supérieur, mais je crois que s'il avait voulu me diriger dans les voies du désespoir, il ne s'y serait pas pris d'une autre façon. (V: 1006)

Parents may begin using criticism as a means to prevent the child from becoming prideful, but it often becomes so habitual that it actually seems as if they are incapable of saying anything positive to the child. Fabien's mother in Si j'étais vous cannot restrain her habitual torrent of condemnations even as her son, Fabien lies seriously ill: Je vais beaucoup mieux, reprit Fabien. Je ne serai plus malade. Je l'espère bien, dit Mme. Especel. Tout le souci que tu m'as donné depuis trois ans...je me demande quelquefois si tu te rends compte de la croix que cela représente pour ta mère.

Un long silence suivit ces paroles. "Ce n'est pas ta maladie que je te reproche dit-elle tout à coup. Naturellement. C'est ton indolence, ton peu de sérieux, ton manque de respect pour tes aînés. (1029)

According to many religions, suffering is good, pleasure is suspect.

Children must learn to subdue their desires, to not expect too much of life and accept disappointment with equanimity. Uncle Firmin clearly believed in this tenet of traditional pedagogy: 


\begin{abstract}
Pendant les quelques années qui suivirent et dans ie plus parfait aveuglement sur lui-même, il savoura le plaisir de surveiller, de restreindre et quelquefois de punir, mais afin de se mieux tromper lui-même, il tempérait sa sévérité triomphante d'un sourire qu'il croyait d'une évangélique douceur, ou bien il soupirait en annulant une excursion projetée depuis des semaines et se déclarait le premier atteint par cette "déception" qu'il offrait à Dieu d'un coeur tranquille. (II: 971)
\end{abstract}

Katharina Rutschkey, in her book Black Pedagogy, cites a passage from a childrearing manual which instructs as follows:

Children especially love the pleasures of the senses. One must occasionally test whether they can control themselves in this regard. Give them fine fruits and when they reach for them, put them to the test. Could you bring yourself to save this fruit until tomorrow? Could you make someone a present of it? (qtd. in Miller For Your Own Good 26)

Marie Therèse was subjected to this kind of Puritan thinking from Sister Louise at school:

Je me souviens qu'en recompense de ma bonne conduite elle me donnait deux ou trois cerises ou un abricot me proposant toutefois d'en faire le sacrifice à Dieu. (II: 223)

Children so disciplined almost never realize they are being manipulated. The greater the child's ability to repress or dismiss his own wants and needs, the more easily he will be controlled.

The following extract from Le Visionnaire is chilling:

Jamais soeur Louise ne me grondait. Un jour que je m'étais montrée un peu remuante, elle me tendit une mandarine et me dit simplement que cette fois je pouvais la manger, parce que je n'étais pas digne de l'offrir au ciel. Je fondis en larmes. (223) 
Marie Thérèse does not see the pernicious aspect of such punishment because it is administered gently by a soft-spoken nun. In fact, that only makes it more insidious. The cruelty of her mother's methods on the other hand, is considerably easier to recognize:

Chez nous, ma mère vengeait les bons principes d'une manière différente. En faisant le tour du jardin, je voyais la cave béer derrière le soupirail, toute prête à m'accueillir à la première désobéissance. (223)

While the manifestations of independence, self-esteem, and emotions are seen as serious threats to the parents' authority, anything sexual (thoughts, feelings or actions) is seen as outright sinful; therefore most earthly pleasures are suspect and the body is seen as evil. Marie Thérèse remembers: “. . j'ôtai ma chemise et regardai mon corps. C'était un acte impur que défendait la religion" (II: 238). From an early age, Julien Green was indoctrinated with the idea that the body is base and disgusting. He recalls that:

Ma bonne s'appelait Lina ... Un jour elle me montra une carte postale qu'il lui avait envoyée. On voyait, je m'en souviens, un Arabe nu qui portait un chiffon autour des reins "pour cacher la misère" m'expliqua Lina dans de grands éclats de rire. Cette gaiété me gêna beaucoup, sans qu'il me fût possible de comprendre pourquoi; et le mot misere devint dans mon esprit une parole abominable et dangereuse à partir de ce jour. (IV: 138)

Parents who think of the body as something disgusting, strive diligently to impress upon their children the shame they themselves feel concerning it. In Partir avant le jour, the author recounts an experience he had with his mother: Ma mère me baignait elle-même. . L'opération terminée, 
elle se relevait et s'éloignant de la baignoire me considérait d'un air désapprobateur. . "Le cou, disait-elle, et maintenant les oreilles et derrière les oreilles" J'obéissais. "Le corps à présent. . .sous les bras et devant ...."Le corps, the body, elle disait ce mot de telle sorte que jusqu'à l'âge de quinze ou seize ans, j'hésitais à m'en servir, comme s'il eût désigné une chose honteuse. . . Un jour, j'étais étendu dans l'eau tiède et ma mère, à trois pas de moi, se séchait les mains d'un air souçieux, quand tout à coup son regard s'abaissa sur une partie très précise de ma personne. Sur le ton de quelqu'un qui parle tout seul, elle murmura: "Oh, que c'est donc laid!" Et elle détourna la tête avec une sorte de frisson. Je ne dis rien, mais je me sentis rougir sans savoir pourquoi. Quelque chose en moi était atteint d'une manière incompréhensible. Je pouvais avoir onze ans et mon innocence était profonde. (701)

However unsettling this experience was for the young Julien, he had

experienced one far more traumatizing years before while he was still a small

child. Not only would he never forget it, it would forever influence his

perceptions of the body and bodily pleasures:

.... un soir, ma soeur Mary se trouva tout à coup près de mon lit. Je ne l'avais pas entendue venir, mais du reste, pourquoi me serais-je caché, ne me sentant pas coupable? D'un geste énergique, elle rabattit la couverture jusqu'à mes pieds et avec un grand cri appela ma mère qui accourut, le bougeoir au poing. Dans la lumière, j'apparus tel que j'étais, ne comprenant rien, souriant peut-être, les mains dans la région défendue. II y eut des exclamations et ma mère posant son bougeoir, quitta la chambre pour revenir armée d'un long couteau en form de scie dont on se servait pour couper le pain. ... "l'll cut if off!" s'écria ma mère en brandissant le couteau à pain ... Je ne comprenais rien à toute cette agitation autour de moi. ... .je fondis en larmes devant le visage indigné de ma mère. (V: 657)

One cannot help but wonder if Mrs. Green had not read a child-rearing manual

by a certain Mr. P. Villaume who was obviously obsessed with sexual "sins" and 
the body. He advised parents as to how they might catch the child "in the act"

without being detected. They were advised to assign a servant or an older

child, someone the child trusted, to spy on him or her:

Send the child to bed early. When they have just fallen asleep, gently pull aside the blanket to see where their hands are or whether you can detect any other signs. . . it will not be long before the little ones betray themselves. (Rutschky 316)

Young as he was, Green was aware that he was being watched:

... ma soeur Mary me surveillait un peu de son grand oeil noir. Je ne sais pourquoi, elle m'épiait, discrètement. (V: 760)

Si jeune que je fusse, en effet, ma mère me surveillait déjà, ayant pour certaines fautes une horreur que je n'ai connue qu'à elle... (V: 656)

If Mrs. Green's object in brandishing the knife was to make an unforgettable impression, she succeeded. For many years afterward, her son would experience shame and disgust concerning everything related to his body. In Mille Chemins ouverts, he wrote:

La honte de l'humanité était, pour moi, tout ce qui se voyait dans la région du bas ventre, j'essayais d'oublier que cela existait. (929)

A few pages farther in the same book, we read:

Ce que j'apercevais malgré moi de tous ces corps ne me causait qu'un dégoût que je ne m'expliquais pas. On ne devait pas être nu, se regarder, passer si près les uns des autres qu'on risquait de se toucher. Tout cela était mauvais. (934)

Green endows many of his characters with a similar aborrence of the body and 
sex. One notable example is Wilfred in Chaque homme dans sa nuit:

Quant aux organes du plaisir, tant chez l'homme que chez la femme, il fallait avoir perdu la tête pour les trouver beaux. Seule l'espèce de crise de folie provoquée par le désir pouvait faire regarder avec indulgence ces régions qui demeuraient suspectes à ses yeux. (540)

Given his training and his subsequent disgust of the body, it is not surprising that the young Julien Green would see sex as a repugnant act. In Terre lointaine, the author recounts the loss of his innocence in so far as his knowledge of sex was concerned when a friend at the university shared some books on the subject: "Le sexe devenait tout à coup d'une importance capitale, avec toute sa laideur et toute sa brutalite" (1193). Many of the characters in Julien Green's novels are encumbered with these kinds of beliefs. In fact some of them, namely Jean's father in Le Malfaiteur, Wilfred, in Chaque homme dans sa nuit, and Joseph Day in Möira, are obsessed by the idea that sex leads to damnation. In a scene from Le Malfaiteur, Jean's father is grilling him on the subject of his tutor Monsieur Paris: " $M$. Paris t'a-t-il jamais parlé du corps humain, de la nudité du corps, du corps d'un homme nu, par exemple?" (289). Jean, who is terrified of his father and has no idea why he is asking such strange questions searches desperately for a suitable response but finds none until:

Tout à coup, je me souvins de ma conversation avec $\mathbf{M}$. Paris dans la salle des antiques. Oui, certes, nous avions parlé de la nudité humainel Avec la précipitation d'un accusé qui veut en finir, je racontai à mon père notre visite au musée. II m'écouta jusqu'au bout, le regard brillant 
derrière ses lunettes, la bouche un peu plus pincée qu'à l'ordinaire. Lorsque j'eus achevé mon récit, décrit les Apollons, rapporté les propos de M. Paris à leur sujet, mon père se dressa subitement et rejeta mes mains comme un objet malpropre. (289-290)

Jean's father subsequently uses the child's testimony to drive Monsieur Paris out of town:

“Ainsi, fit-il en aspirant avec force, ce monsieur s'amuse à promener un garçon de quatorze ans dans la salle des antiques. On feint de vouloir instruire son élève et on sème les mauvaises pensées dans une tête ignorante. Les débris d'un culte honteux, rassemblés dans une salle que l'on devrait fermer, sont mis par ce jeune homme au service de je ne sais quels desseins. Ce qui offense la pudeur est présenté comme admirable. J'écrirai cette nuit à la direction du musée pour qu'on interdise la salle des antiques aux enfants. J'écrirai également au directeur du college où ce malfaiteur répand ses idées, si tant est qu'il borne là son audace. Je demanderai qu'un conseil de discipline examine sa conduite. Au besoin, je ferai une déposition publique et mon fils portera témoignage avec moi." (290)

His father has been very adroit and has achieved what almost all the manuals on child-rearing of the time (nineteenth century and early twentieth) emphasized as absolutely necessary - that the child not be aware of what was being done to him. Not only does Jean not realize that he has been manipulated and used in a most despicable manner; he regards his father as a pillar of righteousness: “. . la colère des "justes" est un spectacle intimidant et je tremblais devant mon père. Sa vertu m'épouvantait" (290). Jean's father was not a just man. In reality he was malicious. He had misplaced the location of the evil pretending it resided in others when, in fact, it was in himself. Wilfred 
in Chaque homme dans sa nuit is, like Jean's father, obsessed by sex. Unlike Jean's father, he is not concerned with other people's sexuality. It is his own sexuality that torments him; therefore, he is not evil as is Jean's father. He is quite the opposite. His carnal hunger is seemingly insatiable yet he is simultaneously horrifed and repulsed by it:

Tôt ou tard, on viendrait s'asseoir près de lui et il y aurait une femme qui lui ferait horreur, mais qu'il finirait par trouver désirable, à force de boire. Ainsi il oublierait la vie, . .. et il descendrait un peu plus bas. (III: 561)

Later:

De retour dans sa chambre quelques heures plus tard, il sentit monter dans tout son être la terreur des jours anciens et se lava à grande eau comme pour effacer toutes les caresses qui avaient pu contaminer sa chair. "C'est par là que Dieu te frappera." (III: 541)

The torture for adults like Wilfred, carefully indoctrinated as children with religious teachings that condemn sex and the body, is that they will forever feel guilty and impure. Since their desire to be pure - to be saved, is as great as their need for sex, one has a crazy-making situation: The more they try to repress their sexual needs and desires, the more they think about them and the stronger they become, terminating in an obsession:

L'épreuve insupportable allait commencer. Entre la faute et le repentir, il y avait un intervalle de dégoût, le dégoût de la chair et le dégout plus horrible encore de la religion. $\mathrm{Ce}$ qu'il allait faire, il le ferait malgré lui: quitter son lit, s'inonder le corps d'une eau froide qui ne purifierait que la peau, s'habiller comme un automate et prendre un livre de messe dans des mains qui gardaient encore le souvenir de la chair qu'elles avaient caressée. (III: 492) 
For Joseph Day, the hero of Moira, the battle between his natural sexual desires and his yearning to be pure and thus attain salvation literally drove him temporarily insane. He had been raised in a very strict religious family. Soon after his arrival at the university, he sits down to write his parents a letter:

Peut-être valait-il mieux ne pas parler de Mrs. Dare et de sa cigarette. Ses parents ne comprendraient pas, s'inquiéteraient. Et s'ils savaient que Mrs. Dare se mettait du rouge ... II posa son crayon. (7)

The following passage leaves little doubt as to the sort of indoctrination he had received. Reading Romeo and Juliet for a class assignment, he superciliously comments:

Qu'est-ce que pouvait lui faire cette querelle entre deux familles italiennes? Et cette passion d'un homme pour une femme, non, pour une fille de quatorze ans? Ce qui l'intéressait, c'était le salut des âmes, et où pouvaient être les âmes de ces gens, s'ils avaient jamais existé? Assurément elles brûlaient. Au moment même ou il lisait leur histoire, dans cette bibliotheque silencieuse, les deux amants rugissaient comme des bêtes sous l'éternelle morsure de la flamme justicière pour n'avoir songé qu'à l'assouvissement de leurs désirs. (39)

Later, while discussing sex with his friend, David, Joseph confesses: "Je hais l'instinct sexuel ... Cette force aveugle, c'est le mal" (86). Then he adds: "Nous sommes conçus dans une crise de démence" (87). Uncertain of his salvation, Joseph agonizes endlessly about his situation - is he saved or not. He also feels compelled to decide whether or noi each person he meets is saved: "Je me demande s'il est sauvé," pensa-t-il tout à coup" (66). David reassures him: 
"Celui qui croit est sauvé" (88). When Joseph learns of David's plans to marry, he is clearly alarmed:

A ces mots, Joseph lui saisit les deux bras comme pour l'immobiliser et le regardant en face, il lui dit avec lenteur: “. . Le mariage est une tentation dangereuse. Que veux-tu dire?

Tu sais très bien ce que je veux dire, reprit Joseph, les yeux brillants. La chair, le plaisir de la chair et toutes les impuretés que cela suppose." (130)

In spite of his religious indoctrination and his total incorporation of its tenets, Joseph can not suppress his physical longings. The resulting agony causes him to cry out to David:

Toi, tu as trouvé Dieu et il ne te sera jamais ôté, mais moi, je tremble à tout moment de le perdre, parce qu'il me semble que je suis plongé dans le péché jusqu'aux yeux. Je brûle, David. . . je désire horriblement ce péché que je ne commets pas. Tu ne sais pas ce que c'est que cette faim du corps. J'ai quelquefois l'impression d'être séparé d'avec ma chair, et c'est comme s'il y avait en moi deux personnes dont l'une souffrirait, et l'autre regarderait souffrir. (148)

Later Joseph is forced to admit that:

La personne qu'il lui importait de ne pas voir - ou de voir (il ne savait plus) - , c'était Moïra. A cause d'elle et du trouble où elle le jetait ... comme il essayait ... de ne pas penser à Moïra. (154)

One night, Moïra locks herself in Joseph's room with him intending to seduce him. For some time, the two affect indifference. Finally they give in to their passion after which, Joseph, consumed with rage and despair, suffocates Moirra whom he sees as the instrument of the loss of his chastity, his superiority (he is now just like everyone else) and any hope of salvation. 
Sex has traditionally been seen as a major $\sin$ in many religions. It should not be surprising that people who ascribe to the tenets of traditional pedagogy should use whatever methods they can to control and if possible, eliminate this very natural and healthy part of life. Parents who have been reared in this manner themselves see all pleasure as suspect. When sex is condemned by the church, when it is blamed for the expulsion of Adam and Eve from the garden, they feel they have a legitimate reason to fight it with whatever means possible.

The use of religion to further all sorts of malefic enterprises has always existed, but using it to tame children, to destroy their wills, to fill their minds with diverse fears and obsessions, not to mention rendering them incapable of ever being the unique individuals they were born to be, seems particularly evil. Alice Miller calls it murdering the child's soul (For Your Own Good 66). At the very least, children victimized in this manner are prisoners. They are compelled to repress any emotions, they are unable to have any thoughts or ideas different from those of their parents, they are denied the right to make their own choices or to act as they desire. The question concerning the use of religion to justify harsh discipline and punishment of children is how it has succeeded for so long without great numbers of religious people seeing the inconsistency between these practices and what Jesus Christ taught:

At the same time came the disciples unto Jesus, saying, Who is the greatest in the kingdom of heaven? 2 And Jesus called a little child unto him, and set him in the midst of them, 
3 And said, Verily I say unto you, Except ye be converted, and become as little children, ye shall not enter into the kingdom of heaven. (King James Bible, Matt. 18:1-3)

6 But whoso shall offend one of these little ones who believe in me, it were better for him that a millstone were hanged about his neck, and that he were drowned in the depth of the sea. (King James Bible, Matt. 18: 6)

10 Take heed that ye despise not one of these little ones; . . . (King James Bible, Matt. 18: 10)

The answer may lie in the fact that in this destructive system of education, the abusers are always victims first. They have been conditioned to respond to anger and punishment. It is what is familiar to them and even what they have been taught God wants. Julien Green's realistic and detailed depictions of the use of traditional education enables the reader to see it in all of its devastating cruelty. Through his pen, accepted ideas and practices suddenly acquire aspects before unseen. 


\section{CHAPTER THREE}

\section{EMOTIONALLY ABANDONED CHILDREN \\ IN THE WORLD OF JULIEN GREEN}

One of the results of a traditional education is the isolation of the child. Traditional upbringing promotes ideas such as: children should be seen and not heard; children are innately bad; to show them any attention is to spoil them; if a parent does not maintain control, the child will wreak havoc and bring disgrace on the family. These kinds of attitudes do not foster close relationships between parent and child. The result being that the child feels quite alone and worthless. He can thus suffer from abandonment even if all his physical needs are met as were those of Emily Fletcher in Green's Mont Cinère. Emily was in no danger of starving to death nor of not having a place to sleep or warm clothing to wear; nevertheless: "Elle eut une enfance solitaire. Toute marque de tendresse lui étant refusée ..." (I: 84). Actually, it is easier for a child to go without proper food and clothing than it is to be deprived of affection and the esteem of one or more grown-ups who clearly value the child as an individual. Denis in L'autre sommeil is an example of a child who did not have the affection of the adults in his life:

Je craignais mon père, et ses accès d'impatience, ses violences verbales, sa voix rauque et brisée d'homme vaincu. A l'égard de ma mère, je n'éprouvais que de la froideur, comme je possédais le bonheur de n'être pas orphelin, elle me jugeait peu intéressant 
et gardait ses chatteries pour son neveu. La plupart du temps j'étais seul et j'y prenais goût. (Green, l: 824)

It is necessary that a child be able to freely express his emotions, his ideas, and his needs without fear of contradicting an adult and thus incurring reprisals; that he have someone in whom he has sufficient confidence to be able to openly share his questions and thoughts. If he doesn't have such a person, the child will feel isolated, abandoned and unworthy of anyone's interest.

The idea that children should be seen and not heard leads to a kind of no-talk rule. It doesn't have to be articulated for it is very well understood simply by the parents' reactions to any attempts on the children's part to break it. The painful loneliness with which so many of Green's characters struggle stems from lack of communication within the family. A good example of the no-talk rule is found in Si j'étais vous:

Quant à parler de ces choses à quelqu'un de la maison ... Personne n'eût été en mesure de la comprendre. En vertu d'une sorte de code lentement élaboré par la famille il était entendu que les questions religieuses se réduisaient à I'horaire des offices du dimanche et que les difficultés d'ordre intérieur n'existaient pas. (Green, II: 979)

It seems likely that this was the situation in the Green family. Mr. Green remembers:

Libéré en juin, j'allai à Rome voir ma soeur Mary ... et je fus surpris de voir un chapelet sur sa table de chevet. Je ne posai aucune question et compris qu'elle était devenue catholique. L'un après l'autre dans la famille nous revenions à l'Eglise, et nous n'en parlions pas. Aborder un sujet religieux nous eût paru gênant. (VI: 923) 
Even more astonishing is the fact that his father also joined the Catholic Church without mentioning it to anyone in the family. Actually, the fact that he stashed a book he was reading on Catholicism under the linens in the linen closet would seem to indicate some effort to conceal his conversion. It was only by chance that his son found it:

Soudain je m'aperçus qu'un livre avait été glissé, comme pour le dissimuler, sous tout ce linge. Je le pris aussitôt et l'ouvris. Le titre ne me disait pas grande-chose. La Foi de nos pères, en anglais, par le cardinal Gibbons, évêque de Baltimore. (VI: 913)

Later, Julien decided that he too wanted to convert to Catholicism. When he informed his father of his decision, the same reticence prevailed:

C'était la première fois que nous parlions de religion et cela nous gênait l'un autant que l'autre. ... Par une pudeur instinctive, ni mon père ni moi ne parlâmes de la religion qui nous unissait maintenant. Chacun de nous avait un secret, le méme. Aucune de mes soeurs restées protestantes ne se douta du changement survenu. (VI: 914)

Wilfred in Chaque Homme dans sa nuit, shared this point of view: "On ne parlait pas de religion, la religion, c'était le plus intime de l'être, c'était le secret" (III: 508). If one cannot discuss religion with family members, with whom can one discuss it? And if one can not discuss religion, what about more intimate matters? What can be discussed? The same things one would discuss with a stranger on a bus? It is unfortunate that the one thing Julien Green and his father had in common did not open the way for some kind of rapport between 
them. It appears that the elder Green did not even attend his son's abjuration

(VI: 921).

The lack of communication, in fact, was not limited to religious matters:

L'idée que j'aie pu voir en lui un père Mesurat est une invention de la psychanalyse, mais je reconnais qu'entre nous les conversations étaient brêves et rares les confidences. Ne sachant pas parler à un vieux monsieur, je réservais à cet usage une voix particulière où les intonations du respect mettaient de longues distances, comme si je me fusse adressé à un étranger de marque, bienveillant certes, mais peu informé de ce que je croyais être moi-même. (V: 1306)

In Partir avant le jour, Green asks himself: "Aurais-je pu dire 'I love you' à mon père? Nous étions l'un devant l'autre à peu près comme deux étrangers" (809). The lack of rapport between fathers and children which exists in practically all of Green's novels certainly accounts for much of the sadness and loneliness found therein. Daniel in Le Voyageur sur la terre, says of his uncle who is raising him:

"Mon oncle ne s'occupait jamais de moi" (I: 20). Jacques Petit says:

L'oncle est un personnage distant, mystérieux (aux yeux de l'enfant du moins car il est banal, comme le sont les personnages de Christine d'ailleurs); l'essentiel est l'absence de toute communication entre son neveu et lui. On retrouvera la même situation dans L'Autre Sommeil, dans Adrienne Mesurat. . . . Sans doute, inconsciente et considérablement transformée, intervient une impression d'enfance: la distance ressentie par Julien Green, entre son père et lui... Cf. Journal, 18 décembre 1959: "Nous nous aimons. Mais entre nous, nul échange n'était vraiment possible." (qtd. in Green, l: 1050)

Reserve and distance seem to have been customary for all members of the Green family: 
A la maison tout change imperceptiblement. Chacun de nous vit dans son rêve comme dans une sphère aussi fragile qu'une bulle de savon, et ces sphères tournent sur elles-mêmes en une incessante et délicate révolution, sans jamais se frôler. Là est le miracle. (Green V: 1336)

Even with his mother whom Green repeatedly assures us loved him deeply, there seems to have been little exchange of ideas or feelings: “. . car toujours absorbée dans ses pensées, elle n'écoutait guère ce que j'avais à dire et répondait: 'Ah?' d'un air distrait. . ." There are accounts of her instructing him in religious matters or of her holding him in front of the fire, but these are not examples of communication. Green himself cannot bring to mind any actual conversations he had with her:

Que n'ai-je retenu ce qu'elle me disait! Mais non, pas un mot ne me revient à la faire parler. Plus j'y pense, plus le nombre me paraît petit des phrases dont je me souviens. Ce qu'elle voulait me dire, elle me le faisait comprendre parfois autrement que par des mots. (V: 758)

Jean-Pierre Piriou points out that:

Si une telle attitude devait nous amener à penser que Mary Green s'occupait beaucoup de son fils, un autre fait d'importance viendrait immédiatement infirmer cette conclusion. Nous savons que la mère comprenait un peu le français mais qu'elle le parlait très mal et qu'elle se servait exclusivement de l'anglais à la maison. Or très jeune, Julien ne comprenait pas un mot d'anglais, et seul le français lui était familier. Comment cela aurait-il pu être le cas si sa mère s'était vraiment occupée de lui et lui avait parlé comme une mère parle à son enfant? Peut-on imaginer quelque chose de plus terrible pour un jeune enfant que de réaliser qu'il ne parle pas la même langue que sa mère! (52)

Being the mother of seven children obviously left Mary Green little time to spend 
with her youngest son and, as is often the case in large families, Green's sisters and members of the household help were responsible for the young Julien:

Comme il fallait me mener en promenade, et ma mère étant trop occupée pour se charger de ce soin, c'étaient mes soeurs qui se relayaient. (Green Vl: 893)

It is curious that, given Mary Green's diligence in reading the scriptures to her children and exhorting them to avoid sin, she would not take advantage of opportunities to discuss religion with them. But it seems that a two-way interchange of concerns and ideas was out of the question. It was while Mrs. Green was reading the Bible to her children that Julien, who had not been hereto-fore able to understand English, suddenly realized he had just understood what she had read: “Je ne me rappelle rien d'autre, sinon qu'à cette découverte j'éprouvai une émotion subite et que me levant je voulus parler, mais on me fit taire" (V: 662). The author also remembers one evening when he very much needed some reassurance and hoped his mother could explain away his fears:

Entre cette mort lointaine et terrifiante du Calvaire et le bonheur éternel du petit garçon que j'étais, je me sentais au-dessus d'un abîme. "Suis-je sauvé?" était la question qu'il ne fallait pas se poser. Je me la posai malgré tout, non sans épouvante, un soir que dans le fond de mon lit remuaient dans ma tête ces énormes problèmes. Ma mère que j'appelai à mon secours me parla avec une fermeté inhabituelle et presque sévère: "Tu crois, par conséquent tu es sauvé, entends-tu?" Tu es sauvé! (VI: 895)

With these words so forcefully emphasized, Mary Green made it clear there would be no further discussion of this subject. Another time: 
Après le service, dans l'avenue de l'Alma, je posais des questions sur le vitrail incriminé et ma mère qui ne comprenait rien à cette histoire m'écartait comme on chasse un moustique. (Green VI: 685)

Except when it was convenient for her, Mary Green did not seem to have the time or the patience to discuss anything with her son. The fact that she was very much occupied with household chores did not escape her son's observation:

... et la mère perpétuellement soucieuse à cause du linge qu'il faut laver ou du linge qui sèche, et des enfants qu'il faut peigner et des comptes qu'il faut faire. ( $V: 651)$

We often find the mothers or mother figures in Gieen's works similarly absorbed in domestic endeavors which leave them little time for the children in their charge. In Varouna, the author paints this portrait of Hélène's Aunt Marguerite who is functioning as a kind of surrogate mother:

... mais elle préférait de n'avoir pas la fillette à ses trousses quand elle veillait au ménage, et comme le ménage commençait au petit jour pour s'achever à l'heure du souper, il ne semblait pas qu'il y eût un instant de toute la journée où fût souhaitable la présence de l'enfant dans la maison de Bertrand Lombard. (689)

The above is not only a description of a woman somewhat consumed by household chores; it is also a window into the heart and mind of a child in such a household. She automaticaliy deduces that she is a nuisance in the sight of the older woman - that household chores are more important than she is. Is this what the young Green felt but could not acknowledge or express? Jean, in Les clefs de la mort, paints an excellent portrait of a mother whose preoccupation with her daily chores leaves her no time for the children: 
Du plus loin que je puisse me souvenir, je l'ai toujours connue douce et bonne, sans gaieté, mais sans amertume, perpétuellement occupée de petits travaux qui ne lui laissaient jamais le loisir de me distraire un peu en me contant des histoires ou de se promener avec moi. . et chaque fois qu'elle nous (Odile et Jean) rencontrait sur son chemin, elle se contentait de nous dire: "Allez jouer" avec un geste des mains que je revois encore, les paumes tournées en dedans, l'une vers l'autre, et s'écartant ensuite à plusieurs reprises, comme pour chasser les moineaux. II importait peu que nous fussions assis à terre, parmi nos quilles et nos soldats, si par hasard elle traversait la pièce où nous nous trouvions, et c'était toujours avec les mêmes paroles qu'elle nous ordonnait d'aller jouer, sans pour cela s'arrêter ni même tourner la tête vers nous lorsqu'elle nous avait dépassés. Nous comprîmes vite, l'un et l'autre, qu'elle disait cela par acquit de conscience, comme pour nous faire comprendre qu'elle était là et qu'elle nous surveillait, et nous n'y fimes plus attention. (529)

That Jean was not in the least deceived by these half-hearted efforts of his mother to appear interested in him is evident :

"A quoi penses-tu donc, Jean?"

Croit-elle que je vais le lui dire? Non, mais elle me voit inquiet et silencieux, et elle me demande à quoi je pense, parce qu'il lui semble que sa conscience l'exige. Ainsi elle m'aura fourni l'occasion de me confier à elle si j'en éprouve le besoin, et elle aura rempli son devoir. Et je réponds:

"A rien. Au temps qu'il va faire." (525)

Jean has long since realized that his mother isn't really interested in what he does just as long as he doesn't cause her any difficulties or in any way impede her progress through her appointed tasks. He also recognizes that his mother's conscience sometimes prods her to make some feeble attempts at appearing to be concerned about him. Children are extraordinarily intuitive, much more so than are adults. They are therefore not easily deceived. 
Communication is a basic skill that in order to be learned must be practiced at home. Because children are not easily duped, they know instinctively that people give time to what they love. If parents do not spend time with their children, if they are not interested in what the child thinks and feels, if they do not share themselves and their thoughts with the child, can anyone be surprised that the child feels alone and unloved? In May of 1926, Julien Green wrote in his journal: "Je souffre d'être seul" (IV: 12), and in June of 1930, he wrote: "La solitude est pour moi une épreuve que je supporte très mal et qui confine au désespoir" (IV: 67). It would seem that Mr. Green recognized to some extent the value of communication in the family when he so poignantly asked: “Pourquoi n'y avait-il pas quelqu'un pour me parler?” (V: 1007). As Jean Sémolué noted of Green's youth: "pas un vrai confident; pas de guide non plus" (68-69).

Green wrote of Hedwidge in Le Malfaiteur:

. . . un élément autobiographique soutient, à l'insu du romancier, cette partie: "Cette fille entourée de silence, du silence de ceux qui pourraient lui dire la vérité et qui ne veulent pas, cela m'a paru vrai." (1396)

We find autobiographical elements in all of Julien Green's works and lonely children are no exception:

Hélène grandit entre ces deux personnes sans rien connaître d'elles que leurs gestes et leurs paroles les plus ordinaires; leurs pensées, en effet, demeuraient secrètes. (II: 708)

The three adults in Epaves, occasionally ask the child, Robert, a question, but 
they do not wait for him to respond. His vacations are well organized with someone assigned to take him somewhere interesting every day; but it is neither his mother, nor his father, nor his aunt. It is always an employee. On the rare occasions when Philippe does spend some time with Robert, he feels he has to hide it from the others. He is afraid it is a sign of weakness to want to be with his son: "Par crainte de paraître comique à leurs yeux, il cachait à sa femme et à sa belle soeur ses promenades avec son fils" (183). Jean Semolué has written of this lack of communication which characterizes the families in Green's novels:

La volonté d'ignorer autrui, le gout, ou l'instinct, du masque, les habitudes débilitantes et mécaniques ruinent totalement les rapports familiaux. Le seul couple uni, capable de créer par la bonté une atmosphère chaleureuse autour de lui, est celui de M. et Mme. Lerat dans Minuit. . . Les autres couples, les autres familles reposent sur le mensonge, l'équivoque, le malentendu et surtout le silence. On pourrait répéter à propos de chaque foyer, depuis Mont Cinere et Adrienne Mesurat jusqu'au Malfaiteur et à Chaque Homme dans sa nuit les appréciations d'Epaves: "Trois ou quatre personnes sont assemblées et vivent sous le même toit qui seraient peut-être contraintes de se quitter sur l'heure, le jour où une discussion maladroite viendrait tirer au clair ce qu'elles avaient sagement tu jusque-là." (75-76)

A child is emotionally abandoned when there is no one who worries about his feelings - about what effects events will have on him. Most adults who have been raised according to the traditional pedagogy concentrate on controlling their child's behavior and they manifest scant concern for any other parental responsibilities such as providing their child opportunities to grow 
emotionally and intellectually. They also fail to recognize their duty to protect their sons and daughters from emotional abuse or trauma. Being victims themselves of traditional pedagogy, they will of necessity have shut down their own emotions and are therefore incapable of acknowledging anyone else's emotional needs. Mary Green certainly was not thinking about her son's emotional stability the night she rushed into his room brandishing a large knife and shouting "l'll cut it off!" Nor was she considering his mental equilibrium the day she thought he had leprosy and made no effort to shield him from the terror she was experiencing:

A la distance de toute une vie, ce n'est pas sans émotion que je revois ces choses. Je me souviens qu'un jour qu'elle me donnait mon bain, elle recula brusquement et poussa un cri: "Ces taches rouges! Qu'est-ce que c'est?" Elle porta les mains à la tête et se laissa tomber à genoux près de la baignoire. "La lèpre!" dit-elle. C'était la maladie dont il était si souvent question dans l'Ecriture. Je gardai un silence horrifié et tout à coup ma mère jeta ses bras autour de mon corps comme pour le protéger. "Je ne te quitterai pas, fit-elle à travers ses larmes, j'irai avec toi à Molokai." Le coeur battant, je lui demandai ce que c'était que Molokai. "Une île. Tu ne sais pas. Les soldats vous forcent à marcher devant eux avec leurs fusils...." (Green, V: 703)

Commenting on this episode years later, Green writes: "Papa et mes soeurs se moquèrent d'elle (sa mère) impitoyablement ... mais je n'oubliai pas la terreur de ma mère" (V: 703).

It is highly unlikely that anyone was looking out for young Julien or was concerned about his mental health when after the death of his mother he slept 
in the same bed in which she had died. Green remembers that in the weeks following Mrs. Green's death, his sister would come to awaken him each morning:

Levée avant le jour, elle venait se tenir au pied de mon lit, celui-là même où ma mère était morte. (VI: 910)

J'étais devenu beaucoup plus sérieux et le jeudi, jour de congé, m'enfermais dans la chambre où ma mère était morte. (VI: 912)

Apparently there was no one who was looking after his emotional needs, no one to protect him from the terrors of death, no one trying to ameliorate the shock of losing a loved one. Given Green's traumatic experiences with death, it is not unexpected that the author should be obsessed with it nor that it should play such a large part in his novels. He wrote in 1932:

En y réfléchissant, j'ai constaté que la plus importune de mes phobies, et la plus persécutante, est celle de la mort. Elle est dans tous mes livres. ... la crainte de mourir s'estelle fait jour dans tout ce que j'ai écrit ... et elle éclate dans le roman qui m'occupe aujourd'hui. J'aborde enfin le sujet qui m'attire, me fascine et m'épouvante. C'est l'obsédé qui se jette dans l'abîme qu'il redoute. (IV: 213)

In a family where there was an unspoken interdiction against the sharing of thoughts, fears or emotions, it is doubtful anyone talked to the young Green about his mother's death or allowed him to express his feelings concerning her loss. These sentiments could only become more profound with time - aided by his sleeping in the very bed in which his mother had died. Similarly, Emily in Mont Cinere is forced to sleep in the same room as her dying grandmother. 
Having never recovered from the trauma of her father's death which had affected her profoundly, she is deeply disturbed by the experience. Jean Sémolué writes:

La découverte de la mort provoque un choc intérieur encore plus grand. Emily n'oubliera jamais la vue de son père mort: “Jamais elle n'avait été mise en présence de la mort. Ce mot de mort, lui-même, n'avait dans son esprit qu'un sens assez vague et le spectacle qu'elle venait de voir lui semblait épouvantable et incompréhensible. (24)

It is understandable that Green's characters would be obsessed with death.

What is interesting is that they are disgusted and repulsed by it as well. No one visits the dying count of Negreterre in Le Visionaire and when Uncle Horace is enduring his last moments in Chaque homme dans sa nuit, family members make their visits to his room as short and as infrequent as possible:

Malgré tous ses efforts, Wilfred ne put trouver en lui un vrai mouvement de charité pour cet homme si près de sa fin, mis il essaya de surmonter son effroi et son dégoût, et parla doucement comme on parle à un enfant. . . (460)

Just as no one showed any concern for young Julien's emotional wellbeing when his mother died, so no one seemed to realize his vulnerability in other areas. It seems the Green family had an inordinate interest in the supernatural. Certain rooms were said to be haunted and Julien's sisters evidently considered him a psychic of sorts. All this had a profound effect on the naturally sensitive child. Green's father only exacerbated the situation with his accounts of a man who had hanged himself in one of the rooms of their home some years previous to the family's renting it. Robert de Saint Jean writes of 
their apartment being peopled with:

... les fantômes dont Mme. Green et, surtout, ses diablesses de filles décelaient la présence, dans tous les logis nouvellement habités. "Une tête de femme se promène dans la chambre d'Eleanor", assurait l'une, ou bien, avec une feinte indifférence, Lucy disait simplement, à la table du petit déjeuner: "I/s ont été terribles cette nuit... (6)

There is no evidence of anyone showing the slightest uneasiness about the consequences of all this on the immature and fertile mind of the child in their midst who routinely cowered on the stairs waiting for the adults to retire because he was too frightened to go to bed alone. This absence of empathy from those whom the child loves, who should by all reason be looking out for his well-being, can only lead to an abysmal sense of being alone. That the supernatural - the mysterious should become one of the major themes of Green's work was a natural result of these childhood experiences.

Children only learn to reach out to others with confidence and compassion if they themselves have been on the receiving end of such attention which unfortunately the precepts of traditional pedagogy preclude. This is the tragedy of Green's characters. They have not been recipients of the kind of care and attention children need to grow into healthy self-confident adults, so they never really do grow up. They remain in many ways, not only children, but abandonned children. Paralyzed by various phobias, obsessions and insecurities, they fear interaction with others and are incapable of addressing their problems. They have no hope of repreive or deliverance for 
they are prisoners locked in their own frightening worlds - unable to act, to love, or, in fact, to live. 


\section{CHAPTER FOUR}

\section{PRISON WITHOUT WALLS: \\ TIMIDITY, A SENSE OF INFERIORITY OR SHAME}

It is the opinion of many psychologists and psychiatrists that raising children according to the precepts of traditional pedagogy will result in paralyzing timidity and a sense of inferiority or shame. Almost without exception, the characters in a Green novel are painfully afflicted by lack of selfesteem, or more precisely, a sense of being defective in some way they can not quite identify. Their tormenting self-doubts and their overwhelming senses of being different from others - of not fitting in, isolate them and limit possibilities for control of their lives as effectively as would concrete prison walls. For these individuals, life is not a marvelous adventure filled with new challenges as well as unexpected delight; for them, life is bleak, monotonous, and above all else, terrifying. Julien Green was himself well-acquainted with these perceptions:

Je n'étais pas comme les autres. Toutes mes difficultés pouvaient se résumer ainsi. Or, mon désir d'être comme les autres et de me réfugier parmi eux me venait quelque fois avec une sorte de violence. Enfant, j'avais connu la tristesse de ne jamais pouvoir faire partie du groupe et m'égayer des mêmes plaisanteries, mais j'étais d'une maladresse comique, je riais au hasard, de confiance. On voyait bien que je ne comprenais pas. Les règles des jeux les plus simples m'échappaient. Colin-maillard, la marelle et les barres me demeuraient étrangers et je restais seul, étonné de ce vide soudain qui se formait autour de moi. (VI: 845) 
If it is not acceptable for a child to express an opinion or even to participate in adult conversations at home; if no member of his family takes the time to converse with him; if no one of those persons who are dearest to him cares to know how he thinks or feels about anything; how can this child ever reach the conclusion that what he thinks and feels is important? Where can he ever get the opportunity to practice and refine his conversational skills if he doesn't get it at home? In Traits of a Healthy Family, Dolores Curran writes:

The healthier the family, the better able it is to accept differing opinions in its midst. . . Members freely say, "I don't agree with you" without risking ridicule or rebuke. They say, "I think it's wrong. ..." immediately after Dad says "I think it's right. ." and Dad listens and responds. Teachers often are able to identify students who come from such families. These students seem confident that their opinions are respected, even if they aren't shared. . . The give-andtake of good family discussion. . .gives children practice in articulating their thoughts at home so that eventually they'll feel confident outside the home. (53-54)

As we have already seen, Julien Green himself was not allowed to contradict his parents nor did he feel free to voice his own opinions at home. Given these circumstances, it was inevitable that Mr. Green would suffer from a lack of ability to converse easily with others:

On pouvait la prendre pour de la modestie ou de la timidité, et il est vrai que mis en présence d'inconnus je restais muet, cherchant en vain une parole aimable ou simplement une réponse à la question la plus limpide ... je manquais d'assurance à un degré incroyable. Entrer dans un salon m'était un supplice. J'avais beau apprendre par coeur des phrases a dire en pareil cas, ou elles me fuyaient ou je n'arrivais pas à les placer, elles venaient trop tard et je 
rougissais. (Green, VI: $846-847$ )

Many of Green's characters suffer from the same affliction and a reader of his novels will vicariously experience the poignant loneliness, anguish, and humiliation experienced by someone so ill-equipped for social intercourse. Joseph Day in Green's Moira is such a person:

II semblait à Joseph que tous les élèves étaient mieux équipés que lui à les entendre parier entre eux. II les trouvait plus rapides de pensée, plus prompts à répondre, alors qu'il lui fallait toujours du temps pour réfléchir et que, sans cesse, il demeurait court. Plusieurs fois, l'idée l'avait effleuré qu'on le jugeait un peu simple, qu'on riait de lui. (37)

Another Green character who is hampered in his relationships because he lacks conversational skills is Wilfred in Chaque homme dans sa nuit:

Il aurait dû partir immédiatement, au lieu de quoi il dit avec un rire qui sonnait faux:

"Beaucoup de choses!"

Quoi, exactement? II aurait voulu savoir, mais n'osa demander ... “Qu'est-ce que vous croyez qu'il va lui arriver à M. Horace? demanda-t-il gauchement. . . Immédiatement, il regretta d'avoir ri et chercha quelque chose à dire, mais ne trouva rien. (432-433)

Philippe of Enaves likewise suffers from an inability to express himself verbally. Actually, in his case, it would be more accurate to say that he suffers from a debilitating handicap which eventually leads him to resign his position with the company his father founded. He is the only one of Green's characters who recognizes a connection between this handicap and his father:

Oubliait-il ses frayeurs d'enfant, la crainte de son père, cette 
crainte presque surnaturelle qui le poursuivait jusqu'ici. Jamais il ne prenait la parole dans cette salle sans qu'une voix de lui seul entendue essayât de le faire taire. De là venaient ses bredouillements et son embarras chaque fois qu'il s'agissait d'exprimer un avis. (86)

One of the factors which imprisons Adrienne in Green's novel Adrienne Mesurat is her inability to speak freely:

Adrienne songea qu'elle aurait pu demander au cocher de lui indiquer un restaurant et un hôtel, et maintenant il lui répugnait d'entrer dans une boutique de déranger des gens attablés pour se procurer les renseignements dont elle avait besoin. (272)

Fabien in Si j'étais vous, too, struggles with verbalization: "Des mots d'excuse tombèrent des lèvres de Fabien dans une sorte de bafouillement qui lui fait honte;..." (867). If, as a child, one is silenced or humiliated every time he ventures an opinion, how can it be expected that he will learn to speak with confidence? Speaking is bound to become an ordeal fraught with all sorts of unforseeable dangers.

Victims of traditional pedagogy, having been constrained in almost all of their efforts to push forward, to be original, to have their own opinions or to act independently, remain, in an emotional sense, children. In order to mature, to grow emotionally, a certain liberty is necessary. If one is forbidden or prevented from pursuing new adventures or ideas, it is difficult to expand understanding, to gain the experience necessary to become a self-confident adult. Jacques Petit describes Adrienne as ". . .une enfant perdue dans un univers qu'elle ne comprend pas, terrorisée, écrasée par les "grandes personnes" qui l'entourent" 
(Green I: 1126). Jacques Petit also recognized the link between Julien Green's immaturity as a youth and Adrienne's when he wrote: 'Julien Green prête à son héroine par référence à ses propres souvenirs, une attitude et une conduite enfantines" (Green I: 1126). The author himself recognizes the child-like attributes of his characters. In Chaque homme dans sa nuit, one reads: "Oh! figure-toi que j'ai perdu un gant sur la route. II avait dit cela comme un enfant" (427). Daniel in Le Voyageur sur la terre is so unsure of himself that he hopes his new friend, Paut, will take charge of finding him a room to rent, but he naturally would never dare ask him to do so: “J'espérai secrètement qu'il se chargerait de toutes les petites négotiations que je redoutais" (37). Jean Semolué also recognized this lack of maturity in Green's characters. In Julien Green ou L'obsession du mal, he noted:

Tous les personnages de Green, si incarnés qu'ils soient physiquement; restent d'inguérissables rêveurs: aucun n'a su vraiment s'arracher à l'esprit de l'adolescence; en outre, les adolescents et les jeunes gens sont les personnages les mieux venus, les plus attachants et les mieux sentis de son oeuvre. (134)

When these characters do find the courage to speak, they almost always embarrass themselves or find themselves saying something they had not at all intended:

Wilfred se voyait amené à dire ce qu'il ne voulait pas dire. (Green, III: 433)

II s'arrêta, ne sachant plus bien ce qu'il voulait démontrer. (Green, III: 425) 
"Tu saisis?"

Wilfred ne saisissait pas, mais il dit: "Oui", (Green, III: 424)

In Moira, Joseph Day is especially plagued by his inability to say what he intends or of saying the opposite:

Ce n'était pas tout à fait ce qu'il aurait voulu dire et il se mordit les lèvres. (69)

Une fois de plus, il n'avait pas dit ce qu'il voulait dire, il avait dit autre chose à la place de ce qu'il voulait dire. (77)

Mais il ne savait pas parler; les mots lui étaient hostiles et se formaient difficilement sur ses lèvres; parfois même il disait ce qu'il ne voulait pas dire. (95)

In Terre lointaine, the author himself observes: "Les mots qui sortaient de ma bouche n'étaient presque jamais ceux que j'aurais voulu dire" (1056).

Mistaking healthy self esteem for the dreadful sin of pride, some parents withhold praise while condemning every flaw and shortcoming. This can only result in the child becoming an adult with a severely diminished sense of his own worth. The use of humiliation (whose real function is to satisfy the adult's needs to feel superior and powerful, thus finally taking revenge for the humiliation he suffered as a child at the hands of adults) destroys the child's self confidence making him insecure and inhibited but more easily controlled.

Victims of criticism and humiliation are literally prisoners of a false perception of themselves. They dare not speak nor act for fear they may appear ridiculous or foolish. Someone so fettered can have little hope of any real sense of accomplishment, of power or even of contentment in his life. Adrienne in 
Adrienne Mesurat was forever on guard against the possibility that she might appear foolish:

“. . elle ne voulait pas non plus sembler ridicule" (386).

... car au fond d'elle-même il y avait toujours la crainte de faire quelque chose qui pût sembler étrange. (417)

Pour rien au monde elle n'eût demandé qu'on lui indiquât un hötel, elle préférait chercher au hasard. . . (287)

Like Adrienne, asking for directions or an explanation seemed to Wilfred in Chaque homme dans sa nuit, comparable to a public admission of his inferiority:

Par amour-propre, il n'avait pas voulu lui demander d'explications (569)

“Je n'aurais pas dû demander," pensa-t-il. (430)

. . . il se sentit médiocre et hypocrite. (425)

Wilfred too was constantly haunted by the idea that he might appear foolish or say something inappropriate: "Wilfred aurait bien voulu savoir combien de temps encore durerait ce petit voyage (III: 415); but like Adrienne, he did not dare ask: "Bien des questions vinrent à l'esprit de Wilfred, qu'il aurait voulu poser au cocher, mais maintenant cela lui semblait impossible" (III: 415).

These characters are afraid to act for fear they will embarrass themselves. Their fear of appearing ridiculous is really irrelevant since that is how they will feel whether they act or not. Wilfred was well-acquainted with this feeling of being defective in some undefinable way:

Cela lui fit honte de rester là, comme s'il attendait quelque 
chose. II aurait dû partir immédiatement. (III: 432)

II avait été maladroit, naîf. Son histoire ne tenait pas debout et Mr. Schoenhals s'était doucement moqué de lui. (III: 533)

Joseph Day in Moïra understood such feelings:

“Moi, j'ai toujours tort d'une façon ou de l'autre." (48)

De nouveau, Joseph hésita à répondre, incertain de ce qu'on allait penser de lui, puis il eut honte de cette faiblesse. (33)

Sans doute, le trouvait-on ridicule à l'université. Chaque fois qu'il s'adressait à un étudiant, il disait quelque chose de bizarre qui provoquait la surprise ou le mépris, oui le mépris de son ignorance, de ses façons campagnardes. Cela il le devinait, il en souffrait. (50)

Fabien, the hero of Si j'étais vous is also restrained by his lack of self confidence and its accompanying fear: ". . . il avait peur de cette boulangère comme il avait peur de tout le monde." (953)

Even some of Green's most aggressive and heartless characters are afflicted with overwhelming insecurity, a sense of always being somehow outof-step with the rest of humanity. Mme. Londe, in Lóviathan, would doubtless seem self-assured to all who knew her but she too suffered: "Mais a peine le garçon avait-il tourné le dos, qu'elle eut le sentiment d'avoir commis une faute . . elle était si peu sûre de luil" (598). And poor Angèle who: "se sentait donc laide et humble. .." (III: 653), flees those with whom she would most like to establish a friendship:

... il y avait des jeunes gens que la pauvre fille regardait avidement, lorsqu'elle les croisait dans la rue. Mais sans 
doute manquait-elle d'audace, car son instinct la poussait à se cacher lorsqu'ils dirigeaient les regards vers elle, et elle leur donnait ainsi l'impression qu'elle était fière et qu'elle ne voulait pas leur parler. (III: 652)

Daniel in Le Voyageur sur la terre, is no stranger to the inexplicable force which compels Angèle to flee contact with those to whom she is attracted. He also avoids people without reason:

De nouveau j'étais troublé et il me sembla tout à coup que je fuyais devant quelqu'un. . . Pourquoi ne suis-je pas comme tout le monde? (45)

The crippling sense of inferiority with which these characters are so tragically shackled keeps them from freely interacting with others just as certainly as would actual chains. It is doubly tragic because in many cases, this disability is the result of well-intentioned, conscientious parents' misguided efforts to educate the child. They want to do what is right and they mistakenly believe their methods will enable the child to become a competent adult. Unfortunately, the rules of traditional pedagogy are abusive and shaming. Shame is:

... a sickness of the soul. It is the most poignant experience of the self by the self, whether felt in humiliation or cowardice, or in a sense of failure to cope successfully with challenge. Shame is a wound felt from the inside, dividing us both from ourselves and from one another. (Bradshaw, Healing the Shame 2)

In Epaves, Philippe tells himself:

Non, mieux valait garder pour soi ces paroles qui lui montaient aux lèvres. On saurait bien assez tôt qu'il n'était qu'un homme ridicule... L'héritage ne valait rien. Un 
bossu au fond d'une échoppe représentait l'humanité plus dignement que lui. (68)

When a child is punished for getting angry, being sexual or sad, he does not know that these are basic healthy emotions which everyone feels. He assumes that his parents or guardians are always right so when they chastise him, he not only accepts their judgement as the absolute truth, he is ashamed because he feels that no one else has ever had the same feeling. He is therefore convinced something is wrong with him - that he himself is flawed in some way. In Le Malfaiteur. Jean tells Hedwige:

.. j'entendis le plus distinctement du monde une voix murmurer: "Encore un qui flanchera tôt ou tard. ..." "Oui," fit une autre voix au bout d'un instant. II m'en a tout l'air. .." J'éprouvai d'une façon pénible le sentiment de mon insuffisance. (314)

Hedwige in turn, is tormented by her own lack of self confidence:

La jeune fille passa d'abord sans entrer, jetant un regard d'une négligence étudiée sur deux bergères Directoire qui se carraient dans la devanture . . . puis s'étant éloignée de quelques pas, elle s'arrêta. Qu'allait-elle dire à cette femme? Elle ne trouva rien . . . Tout a coup elle se vit dans la glace d'un pâtissier et crut entendre la voix dentale d'Ulirique: "Tu es habillée comme pour un mariage." Son coeur se serra: c'était vrai. Bien pire: le mot qui convenait à sa toilette lui monta aux lèvres dans un gémissement: "Endimanchée!" "... je rentre", pensa-t-elle, désespérée. Au lieu de quoi, par une résolution soudaine, elle se dirigea vers le magasin. (314)

The overwhelming burden of the ever present sense of being defective, appearing ridiculous, worthless and stupid not only paralyzes but can become so unbearable that as in Hedwidge's case, it leads to suicide. 
A person who feels he is defective, becomes hyper-vigilant out of fear that others will discover his deficiencies. He will not be capable of speaking spontaneously or of speaking without weighing each word. This will make him appear a bit "gauche" and will in turn confirm his feelings of inferiority. In Jeunesse, Green Writes:

Que je me sentais gauche cependant, incapable de discuter de conduire un raisonnement jusqu'au bout devant ces garçons qui maintenant parlaient entre eux comme si je n'étais pas là. (1432)

John Bradshaw refers to shame in Healing the Shame that Binds You as: "The all pervasive sense that I am flawed and defective as a human being" (10). Jean in Le Malfaiteur tells Hedwidge: "Je fus obligé de convenir que j’avais honte de ce que j'étais" (314). We find the same sentiment in Mille Chemins ouverts: "Pour la première fois de ma vie, j'avais honte d'être moi-même (935), and in Le Vovageur sur la terre: "Pourquoi ne suis-je pas comme tout le monde?"( ). Green says of Wilfred: "ll voulait surtout se cacher. . quelle honte de se montrer aussi peureux à vingt-quatre ans!" (III: 435). Wilfred “. . . ne voyait jamais deux fois la même femme" (III: 500). It is likely he was afraid that if they got to know him, they would discover he was inferior. Whatever the reason for this practice, it prevented him from forming any relationships and thus it isolated him from the rest of the world.

Fear of betraying oneself if one is not constantly on guard, results in selfabsorbtion. A shame-based person will watch himself constantly, conducting a rigorous examination of each minute detail of his actions. Internal critical 
observation is frightful. It creates a tormenting embarrassment that the psychiatrist, Gershen Kaufman, describes as creating a paralyzing selfmonitoring of the interior which produces retreat, passivity and inaction characteristics shared by most of Green's characters. This is the situation in which Philippe (Epaves) finds himself. He doesn't live his life - he simply exists. The only energy he seems to exert is when he resigns from the board of directors of his father's company because his insecurities and fears render the meetings intolerable. Even when he witnesses a woman being beaten and in danger of losing her life, he cannot go to her aid. Philippe confesses that "je manque d'énergie, d'assurance, je ne sais pas résister aux gens qui viennent me demander de l'argent, et par-dessus le marché, j'ai peur au fond de moi, j'ai peur de presque tout le monde" (67-68).

Constant internal monitoring leads to narcissism. Gershan Kaufman believes that shame is the affect which is the source of many complex and disturbing inner states, including a deep sense of inferiority and narcissism. Philippe's habit of gazing into mirrors is an example of such an affect. Philippe needs continual assurance that at least he doesn't look inferior or flawed. He is constantly on guard lest someone find him out. Depressed, he thinks: "On saurait bien assez tôt qu'il n'était qu'un homme ridicule. Sa femme le savait déjả . . Au moins, pensa-t-il j'ai une bonne santé et je ne suis pas difforme" (II: 68). At a memorial service for his uncle, Wilfred can think of nothing but himself and what others are undoubtedly thinking of him: 
... il avait un peu honte de se trouver là, car, pensait-il, tout le monde savait qu'il était vendeur dans un magasin. Il était sûrement le plus jeune et le moins riche de tous, le fils de I'homme qui n'avait pas réussi. S'il était question de lui dans ce testament, ce ne pourrait être que d'une manière insignifiante ou qui prêterait à sourire. D'une façon ou de l'autre, il allait s'exposer à une humiliation. (III: 554)

One of the characteristics of a shame-based personality is inordinate blushing. Blushing as a manifestation of healthy limits or healthy shame is good. It keeps us as John Bradshaw says, from being "carried away with our own excellence" (Healing The Shame That Binds You 7). However, inordinate blushing is not healthy. Scott Peck said that "When neurotics are in conflict with the world, they automatically assume that they are at fault" (Bradshaw Healing The Shame That Binds You 9). Wilfred is a good example of someone who is encumbered with such a sentiment: ". . . et sans savoir pourquoi il se sentit coupable" (III: 674). The outward manifestation of feeling guilty or ashamed is the inordinate blushing with which many of Green's characters are afflicted. In Terre lointaine, Green himself remembers that as a young man: "Les mots qui sortaient de ma bouche n'étaient presque jamais ceux que j'aurais voulu dire, je me trompais, je rougissais comme un écolier coupable" (1056). Daniel in Le Voyageur sur la terre, blushed often: "Je me sentis rougir" et "Je devins rouge" $(35,38)$. Mme. Londe "sentit que les joues lui brûlaient" (I: 734). However, Joseph Day and Wilfred are the most severely affected. Wilfred can scarcely do anything without feeling shame:

A sa propre stupeur, Wilfred se mit a rire sans pouvoir dire pourquoi, mais aucune explication ne lui fut demandée et 
brusquement il se tut le rouge au front. (III: 510 )

La honte lui envoya une bouffée de sang au visage. (III: 519)

In Moïra, Joseph Day is no less afflicted:

Le sang monta au front de Joseph qui baissa les yeux, et tout à coup il eut conscience de ses origines plus modestes que celles de ces deux personnes aux manières si réservées. (112)

... .car il rougissait de plusieurs phrases qui lui avaient échappé. (149)

Blushing reinforces the sufferer's sense of inadequacy because to him it is a visible manifestation of his inferiority. Blushing not only indicates a sense of inferiority; it is also indicative of a sense of guilt - guilt for actions that cannot be elucidated. Julien Green wrote:

...e et j'eus une fois de plus le sentiment que quelque chose m'échappait, que pour des raisons incompréhensibles, on n'était pas content de moi. (V: 989-990)

To feel that oneself is flawed, shameful and guilty is an overwhelming burden. It puts one in an impossible situation because one doesn't know exactly what is wrong with him or what he is guilty of, and therefore he can take no steps to ameliorate the situation. He is virtually paralyzed. This is the situation in which many of Green's characters find themselves Like Adrienne, Phillipe and Hedwidge, they seem powerless to take charge of their lives.

Through the suffering of Green's characters which he so poignantly describes, we see how a child reared according to the nefarious guidelines of traditional pedagogy, deprived of a sense of self-worth, or self confidence, 
convinced he is somehow defective and certainly inferior, will suffer from paralyzing timidity which will separate him from the rest of the world as surely as would concrete walls. He not only cannot reach out to anyone; he flees contact with others even when he desires it. He is thus separated from the rest of humanity as surely as if he were behind bars. Jean Cassou, cited in Julien Green par lui-même by Robert de Saint Jean has this to say about Green's characters:

Chacun demeure enfermé dans son existence comme dans une manie. C'est que chacun a peur. Peur de lui-même et peur du monde. (87)

Julien Green himself recognized the existence of invisible walls around himself. He wrote: “. . élevant autour de moi ces affreuses murailles" (V: 1026), et "Les murailles invisibles qui s'étaient élevées autour de moi dans mon enfance tenaient bon" (V: 1040). 


\section{CHAPTER FIVE}

\section{FROM TRADITIONAL PEDAGOGY TO VIOLENCE AND DEATH}

Individuals raised according to traditional pedagogy are constrained to repress their emotions, which eventually destroys their self-confidence. In an effort to take charge of their lives, they attempt to reduce their chances of failure or embarrassement; thereby gaining some control over their lives. The combined stresses of suppressed emotions and the futility of trying to manage everything in one's environment are lethal and result in violence, either against oneself or against others. Ironically, people so afflicted do not gain control over their lives and environment, which is, of course, impossible; instead they find themselves imprisoned in a prison without physical constraints. The only way to escape is through madness or death.

Traditional pedagogy allows parents and other care givers to vent their frustrations and anger on the children in their charge while denying them the right to react. Repressed anger does not evaporate; it festers and grows until a legitimate way to express it can be found. If no such outlet can be found, the anger erupts in violence, often senseless violence. The most commonly accepted way for adults to discharge their burdens of accumulated anger, is to use it to "discipline" their children. Alice Miller has wondered if there would 
have been a holocaust if Adolf Hitler had had children on whom he could have vented the pent up rage he had accumulated as a result of the many brutal beatings he had received from his father (For Your Own Good xi). Suppressed anger, however, does not always lead to violence against others; some victims turn their anger against themselves. Ms. Miller explains that:

The greatest cruelty that can be inflicted on children is to refuse to let them express their anger and suffering except at the risk of losing their parents; love and affection. The anger stemming from early childhood is stored up in the unconscious, and since it basically represents a healthy, vital source of energy, an equal amount of energy must be expended in order to repress it ... [Which] sometimes leads to suicide or extreme drug addiction, which is a form of suicide. (For Your Own Good 106)

Julien Green's writings, are replete with violence directed at others as well as oneself. His characters are well-schooled in the practice of denying one's emotions and do not for a moment dream that doing so is unhealthy, dangerous, and sometimes lethal. It is the reader of a Green novel who sees the tragic results of this unhealthy training unfold. Someone conditioned by the precepts of traditional pedagogy is desensitized to all pain - his own and others'. This enables him to in turn mistreat others by discharging his pent up anger on them. In his desperate efforts to avoid any more humiliation, pain and exposure, he comes to believe that the only important thing is control - not just over one's emotions but over everything in one's environment. In order to facilitate and maintain such command over the events of one's life, it is necessary to shrink one's world as much as possible, cutting off all 
unneccessary interaction with others. Eventually, the combined stresses of the repressed emotions and the frustrations of never being able to control everything are too much and violence erupts. Such is the history of many of Green's characters. Adrienne in Adrienne Mesurat went mad as did Max in Chaque homme dans sa nuit. Daniel in Le Voyageur sur la terre commits suicide as do Jean and Hedwidge in Le Malfaiteur. Joseph Day who murders Moïra in Moïra and Gueret in Leviathan whose brutal beating of Angèle results in her disfigurement and eventual death, expel their rage in violence against others.

Green's characters must, like all victims of a traditional upbringing, learn very early in life to submit to the anger and violence of their parents, not only without protest, but without condemnation. Idealization of parents and gratitude for their having given one life is required for this system of education to work.

Toi, fit oncie Douglas, le doigt tendu vers Mike, en fait de réconciliation, nous allons arranger cela tous les deux, dans ma bibliothèque et les portes fermées. Qu'est-ce que j'ai fait? Je compte te le faire comprendre d'une main ferme, mon garçon. . Quant à toi, Johnnie, fit Oncle Charlie, cesse de pleurnicher comme une demoiselle; tu me fais honte. Tâche d'être un homme. (Les Etoiles du sud 457)

Johnnie was only four years old! Adrienne Mesurat knew what it was to suffer the verbal and physical abuse of her father without protest. M. Green wrote of her life, ". . . elle vivait au jour le jour, courbant la tête sous les colères du vieux Mesurat" (I: 373). 
A child's anger, sadness, or fear can be repressed, but it cannot be eliminated. Denis in L'Autre Sommeil remembers:

“. . . ma mère ... nommait bouderie cette victoire sur mon impatience et me reprenait avec des paroles qui fomentaient dans mon coeur une colère dévastatrice. (841)

In order not to feel accumulated pain, Green's characters, like other victims of traditional pedagogy, must learn to block their emotions. M. Green, having received a strict Puritan unbringing, understood the process well for it is something he often describes doing himself, "Je dévorais mes colères" (V: 888).

Similarly, Wilfred in Chaque homme dans sa nuit, had been so thoroughly conditioned to believe anger was a great sin that he could not bear the guilt which accompanied it. In his case, it was necessary to immediately repress or deny any feelings of anger, thus convincing himself that he had already forgiven the one who had wronged him:

Jamais il n'avait pu garder de rancune plus d'une minute, quelle que fût la colère où on l'avait jeté. Pardonner, effacer lui procurait un bonheur étrange qui lui faisait battre le coeur. (426)

Perhaps the strange happiness he experienced after forgiving someone was actually a release from the fear of God's judgement which he had been taught was meted out to those who were angry and did not forgive. In any case, it was sentiments such as these that prompted Wilfred to return to Max's apartment seeking the latter's pardon, even though he recognized that, “. . l'idée de demander pardon à quelqu'un comme Max semblait par-dessus le marché 
ridicule et dégradante" (III: 689). Nevertheless he went. And that night, Max in a delerious rage, killed Wilfred. Wilfred had good reason to be angry with Max but his driving need to apologize and wipe out all enmity would not permit him to harbour any resentment or even to admit that not only had Max been at fault but that it was dangerous to try to see him again. So it was that Wilfred's denial of what had actually happened led him to his death.

Denying pain, anger, sadness, or frustration is not always an unconscious act, not even for those who have practiced it all their lives, "Une rage subite saisit Wilfred qui se mordit les levres" (III:414). Sometimes it takes extraordinary willpower and strength, as it often did in Joseph Day's case: ... et il eut envie de faire claquer la porte; toutefois il parvint a se dominer et la referma, au contraire, le plus doucement qu'il lui fut possible, mais sa grande main blanche serra le bouton en cuivre avec tant de force que longtemps après, il eut l'impression de le tenir encore dans sa paume. (III: 123)

Whether or not his anger was legitimate was not important; the only thing that mattered was not venting it. This was a daily struggle for Joseph, sometimes an hourly one, "La rage au coeur, Joseph obéit" (III: 24). In Mont Cinère Emily Fletcher also had to struggle to keep her emotions under control: . . e elle était obligée de se courber en deux et de se mordre les lévres pour ne pas céder à un étrange désir de pleurer ou de crier ... . ses mains se crispaient sur la toile et plusieurs fois elle cassa son fil tant elle mettait de violence à tire l'aiguille. (73)

All emotions are to be avoided, not just those considered negative ones such as anger. When Manuel, in an élan of affection, reaches out to embrace his aunt, 
she repulses him, shaming him and sending the very clear message that there is something ignominious about displays of emotion:

Des larmes d'émotion me montèrent aux yeux et je fis un mouvement vers elle comme pour l'embrasser, mais elle me repoussa du coude.

"Va te coucher, toi" dit-elle." (II: 304)

Philippe in Epaves also finds unsuppressed emotions distasteful, "Une telle explosion de chagrin lui semblait d'une impudeur odieuse" (137). The mistake Green's characters make is thinking that one can just push aside one's emotions and thus be rid of them. M. Green describes Mme. Londe as subscribing to such a belief:

A quarante-cinq ans elle en était encore à croire qu'on peut se défaire de ses passions en n'y songeant pas, de même qu'un juge fait jeter un criminel au cachot et s'en va dîner. (I: 785)

A tragic effect of blocking emotions is that the mind is not selective; all emotions are blocked - even desirable ones such as compassion and affection. After a lifetime of shutting down all emotions, Denis of L'Autre Sommeil should not have been surprised that, like Meursault in Camus' L'Etranger, he felt nothing when his mother died, "Je m'en voulus à ce moment de ne pas avoir les sentiments qu'il fallait" (1: 858). Hedwidge does not feel the smallest part of sympathy for Félicie even though she recognizes that she is humiliating her. She is not even aware of any reason why she should mistreat the strange little seamstress. Hedwidge is, of course, completely unaware of the fact that in treating Félicie the way she does - by discharging her anger on Felicie - she is 
getting revenge for all the pain and humiliation she has suffered herself:

Hedwige paraissait mécontente et gardait un silence épouvantable. Quelque chose qu'elle ne s'expliquait pas bien la poussait à humilier cette femme qui se tenait debout devant elle comme une accusée devant son juge. (III: 365 )

Like Hedwidge, Marie in Minuit has no idea that her treatment of her sister discharging her anger on Clémentine, allows Marie to get some revenge for the pain and humiliation she has herself suffered:

Mais elle l'aimait comme on aime sa victime et elle la rudoyait pour le simple plaisir d'exercer sa force. (406)

The phenomenon of a victim becoming a victimizer is tragically ironic for it enables the system of abuse to continue. It is not uncommon for Green's characters to inflict on others the same pain they themselves have endured. Joseph Day (Moïra) who comes from a puritanically strict religious family with a violent father becomes a murderer. Max chaque homme dans sa nuit, an obviously troubled young man trying to deal with the pain in his life, kills Wilfred. Mrs. Fletcher (Mont-Cinere) who is a frightened submissive daughter whenever she has to deal with her mother Mrs. Elliott, is a tyrant in all that concerns her own daughter Emily. In Léviathan, Mme. Londe, whom we first see as an arrogant overbearing manipulator who severely mistreats and uses Angele, is actually so insecure and frightened that she dares not even leave her home: “...sous des dehors d'aplomb et de fermeté, cette femme était toute timidité, toute faiblesse (786).

Adrienne Mesurat provides us with a shocking example of anger, rage, 
and the capacity for violence being passed from parent to child. In the case of Adrienne, however, she does not pass her demons onto an innocent child. Instead she unleashes them against the very person who gave them to her. Adrienne has never mastered the art of blocking her emotions and has never embraced the idea that parents are flawless: “. . . sa fille qui attachait sur lui un regard à la fois curieux et dégoûté" (346-347).

Adrienne recognizes the tendency for victims to become victimizers. Remembering her former French instructor, she thinks: "Sûrement, elle avait dû traverser des moments difficiles au cours de sa vie pour être devenue aussi méchante" (313). She herself was very familiar with the accumulated rage which can result from repeated submission to another's anger: "Elle gagna sa chambre dont elle referma la porte avec violence:

Une colère subite la fit frapper du pied et, tout d'un coup, elle se jeta sur son lit, cachant son visage brûlant dans l'oreiller . . Elle se redressa sur un coude et, du poing, elle martela l'oreiller en répétant à mi-voix d'un ton furieux: “Idiote! Idiote! (308).

Tragically, it was a similar explosion which would later result in the death of her father and her own madness. After being forced to submit to a particularly abusive and violent diatribe from her father, in which he not only strikes her repeatedly and threatens to kill her, but also states his intention to disinherit her and to ruin any chance of a relationship with the Dr. Maurecourt, Adrienne:

. . s'élança hors de la chambre et ferma la porte derrière elle à toute volée. . . Une horrible frayeur la saisit et, sans savoir comment, à peu près comme si elle eût été jetée dans le noir par une force irrésistible, elle se rua vers l'escalier; tout son poids porta sur les épaules de son père 
qui perdit l'équilibre et tomba en avant, tandis qu'elle se retenait à la rampe. (390-391)

An expert on family relations, John Bradshaw, offers some insight into the problems of people who abuse others either verbally or physically, which could very well apply to numerous Green characters:

The abused child in the persecutor is angry and hurt. The anger is forbidden in relation to his parents so ... it is either projected onto others, turned against self or "acted out" (addictions). (Bradshaw on: The Family, 70)

It is therefore completely logical that in Green's novels, where children are raised according to the dictates of traditional pedagogy, where so much anger is repressed, that there would also be a lot of violence. Jean Sémolué points out that there exists: " . . une tendance profonde du personnage greenien: devenir un bourreau - ou parfois une victime - ou parfois les deux" (80).

Stifled emotions almost always lead to unexpected outbursts of anger. It is significant that most of the violence committed in Green's novels is not the result of careful planning, but rather of seemingly spontaneous, uncontrollable explosions of violence. In fact, the perpetuators of these acts are often as surprised and bewildered as anyone else by their actions. After savagely beating Angèle, Gueret poignantly demands:

Comment se pouvait-il qu'il eût fait cela et, surtout pourquoi l'avait-il fait?

L'âme sera-t-elle toujours tenue responsable de ce que fait le bras, de ce que dit la bouche? Pourquoi n'y aurait-il pas des moments où s'accomplit un divorce entre les actes de l'homme et sa volonté? Peut-être servons-nous quelque fois des forces que nous ne connaissons pas et qui profitent 
du désordre où nous jette la fureur pour se substituer à nous et guider nos gestes. ( $1:$ 768-769)

Likewise, Wilfred's attack on Max was unpremeditated; in fact, he would have been hard put to find an explanation for his actions:

... que par un geste de colère il dégagea sa main, et sans savoir pourquoi, il le gifla, et comme Max ne bougeait pas, il le gifla de nouveau, et encore, pendant près de deux minutes. (III: 606)

The probability that the idea of suffocating Moirra never occurred to Joseph Day until after the fact is strong:

"J'ai froid!" murmura-t-elle.

"Tu as froid", dit-il d'une voix changée.

$\overline{E t}$ ramassant à pleins bras la grosse couverture grise. . . il

la fit retomber soudain sur la tête de la jeune femme. . II soufflait, courbé sur elle. Des mots sans suite lui sortaient de la bouche et à un moment il pleura sans le savoir. Lorsqu'elle fut parfaitement immobile, il poussa un profond soupir et souleva la couverture, mais devant ce visage qui le regardait, il fit un pas en arrière et demeura silencieux. (III: 174-175)

One can only wonder if he would have killed her had she not fought back - if she had just lain there.

In Mille Chemins, Julien Green wrote of himself: "Un meurtrier dort au fond de nous-mêmes; C'était de lui que j'avais peur. Ma douceur ne s'expliquait pas autrement. Je dévorais mes colères" (888). A good friend of Green's, Robert de Saint Jean emphasizes the connection between stifled emotions and violence. In Julien Green par lui-même, he writes: “. . il n'y a pas, dans leur jeunesse, de fils plus obéissants que les futurs romanciers de la violence et de la révolte" (35). It seems logical to conclude that writing about 
violence is a kind of therapy, a legitimate means of discharging the pent-up submerged anger.

In his autobiography, Quand nous habitions tous ensemble, the author describes the daily session of scripture-reading conducted by Mrs. Green for the instruction of her children:

Le livre refermé, ma mère posait des questions auxquelles il valait mieux répondre correctement, car sa main volait audessus de nos têtes comme un oiseau vengeur et punissait l'étourderie avec une sévérité toute mosaïque. (813)

M. Green hastens to add: 'A dire vrai, je n'avais rien à craindre, car n'ayant guère plus de cinq ou six ans, je n'étais pas tenu d'écouter" (813).

It is not unusual for a child of a family where physical punishment is used, to become "The Perfect Child." A small child seeing his older siblings physically and verbally punished can be so traumatized by the violence that he will do anything to save himself and thus preserve his parents' love. He can not consciously entertain the thought that his favored status has nothing at all to do with who he is; that if he were to slip, to assert himself, he too would be in disfavor. Unconsciously, he knows it only too well. So in order to survive, thoughts, feelings, desires, even dreams must be denied and never allowed to surface. Displays of emotions, such as tears on the part of another, threaten to penetrate the protective walls one has built around his own pain. Victims of traditional pedagogy, insecure and frightened, live in constant fear of losing control - of not being able to cope and thereby allowing their pent-up anger, sadness, pain and frustration to explode. Desperately they strive to maintain 
order in their lives. This is particularly evident in Varouna. Referring to Marguerite, Green wrote, ". . . et comme le ménage commençait au petit jour pour s'achever à l'heure du souper. .." (689). The mother of Jean in Les Clefs de la mort was obsessed about cleanliness and orderliness which was in reality not so much about housekeeping as it was about controlling her environment and attempting to find some security: ". . . les soins du ménage l'ont reprise tout entière, et elle ne pense qu'à ses draps, ses mouchoirs, ses chemises où elle tremble de découvrir un trou, une déchirure" (526).

The compulsion to maintain order does not only manifest itself in the need for physical order. We see Philippe in Epaves constantly monitoring and evaluating his actions in order to avoid doing anything that would make him appear foolish or reveal a weakness. Joseph Day in Moïra feels responsible not only for keeping his own actions within strict boundaries; he also feels responsible for the souls of those with whom he comes into contact: ... il se vit arrachant à cette femme des larmes de honte, des promesses, un vrai repentir, peut-être me̊me une confession publique de ses fautes, comme cela se faisait jadis. Quelle victoire! (10)

Because it is impossible to exert much influence over so much of what happens to us in life, Green's characters often isolate themselves in order to reduce the scope of things to be dealt with. In their small spheres of responsibility, they continue making every effort to exert maximum control over their environment and whomever they can. It is a desperate and futile struggle to protect themselves from the vicissitudes of life. 
This compulsion to avoid the challenges of life explains why almost all of Green's characters are solitary personalities: Mrs. Flectcher (Mont-Cinère), Mme. Plasse (Le Visionnaire), Wilfred (Chaque homme dans sa nuit), Joseph Day (Moïra), Jean and Hedwidge (Le Malfaiteur ), Philippe and Elaine (Epaves), to name a few. Their lack of self-confidence contributes to their isolation, but above all, they are desperately afraid of losing control. As children, the loss of control had frightful repercussions. Now as adults, in order to protect themselves, they shrink their worlds as much as possible, thereby reducing the possibilities of failure. Philippe in Epaves effectively accomplishes this by resigning his position on the board of directors of his father's company. Hélène's father (Varouna) sequesters himself in his study most of each day as does Daniel's uncle (Le Voyageur sur la terre). Mrs. Flectcher (Mont-Cinère) only leaves the house for a sale. She sends Emily out to conduct any business which needs to be attended to:

Mrs. Fletcher instinctively touches the furniture or leans on the walls whenever her self-created world is threatened - as for example, when the pastor comes to solicit money or when Emily brings home a husband. (Kostis 25)

Whenever something unexpected happens, it reminds her that in reality, she has very little, if any, control over her life. She reaches out to the walls and furniture because these things have always been or so she thinks, her defense against the uncertainties of living. Her avarice is motivated by her fear and the need to control - her only defenses against the caprices of life. Julien Green realized this when he wrote of Mont Cinère, "Tout était donné, tout s'y trouvait 
en substance, ma faim, mes inquiétudes, l'effroi de vivre" (IV: 945).

M. Mesurat's defense against his fear of the world and life consists of rules and rituals which make him feel secure and give him confidence, " $M$. Mesurat fronça le sourcil; il n'aimait pas ce qui sortait de l'ordinaire" (I: 293). When he can not control what happens around him, such as when he goes out, he feels frightened and vulnerable: "Mais, jovial et tyrannique chez lui, il était d'une timidité d'enfant dès qu'il avait franchi la grille de la villa des Charmes" (I: 292). The man's need for control extends well beyond household routines. When his efforts to ignore, repress, even deny Germaine's illness fail, his sense of insecurity is heightened and his terror manifests itself in his cruelty towards her. Since he cannot admit that she is ill, he must assume she is faking it and so he seeks to forcefully persuade, intimidate or shame her into giving up her game. The only problem is that she is not faking. However, by increasing the pressure on her until she leaves, he wins. Once she is gone, she can not interfere with the control he exerts at la villa des Charmes and his serenity is no longer threatened by her illress.

Nicholas Kostis recognizes this fear of life that is so typical of Green's characters. Describing the parents of Denis in L'Autre Sommeil, he explains that they:

... reject life, reducing it to a mere function of existing. What we call life is not seen by them as a positive moral or material substance but as the content of failure, discomfort, and negation. Existence, as distinguished from life, is seen as a systematic effort, both physical and spiritual, to exclude the threats which are implicit in life. (51) 
As much as Adrienne resents her father's tight hold on her actions, she too is afraid of life. After M. Mesurat locks the iron gate preventing his daughter from leaving the villa and perhaps seeing and speaking with Dr. Maurecourt, Adrienne reflects: “C'était peut-être moins affreux d'être plongé ainsi dans un ennui sans trêve que de passer fiévrieusement d'un instant de joie inquiète au plus cruel des chagrins" (I: 355).

The irony is that people who seek to manage everything in their environments eventually find themselves with little control of anything. They virtually create their own prisons. Fabien in Si j'étais vouss makes a deal with the devil in order to escape the prison that is his body. He mistakenly believes that if he were someone else, life would be more bearable. A large number of Green's characters are prisoners of their bodies, minds, families, upbringings, or all of the aforementioned. Fearful of losing control of their lives, of their emotions, of making incorrect decisions, appearing ridiculous, stupid, or cowardly, they prefer to withdraw. Never having been given the chance to experiment, to express themselves, to contradict another, or to feel any emotion, they lack social skills and harbor crippling feelings of inferiority. Attempting to minimize the possibilies of failure and humiliation, they seek security in withdrawal from the world and take comfort from the old familiar rules with which they were raised. Though there are no walls, locks, or bars, they are prisoners virtually incapable of escaping the tormented lives to which their upbringing has condemned them. Green himself acknowledges his characters are prisoners, 
as is seen by the following entry in his journal, "Mes livres sont des livres de prisonnier qui rêve de liberté" (IV: 1118).

M. Green elaborates on the themes of prisoners and prisons in Fin de Jeunesse:

... comment ne pas découvrir une manière de consanguinité entre Adrienne et les violents solitaires de mes autres récits? Si la jeune Française étouffe entre les murs invisibles de sa prison morale, Karin la Danoise se promène comme dans une geôle au sein d'une ville qui feint de ne pas la voir. N'exceptons pas de ce groupe de Joseph de Moïra enfermé dans sa vertu sans faille dont il ne pourra s'évader que par le crime. Tous devenus comme dans le vers de Milton le donjon d'eux-mêmes. (855-56)

Others have recognized the prisoners in Green's narratives. Jean Sémolue has written:

L'orgueil, l'indifférence agressive, la violence haineuse et le sadisme affirment une volonté de solitude. Le désir, à l'origine, répond à un besoin d'évasion. Mais il va, lui aussi consolider la prison. (Sémolué 85 )

Commenting on the theme of the prison, Jacques Petit explained the following phrase from Si j'étais vous, "C'est ma faute... C'est ma très grande faute" he wrote:

Ce sont les réactions d'Adrienne Mesurat refusant de répondre au jeune homme qui l'aborde et ensuite cherchant à le rejoindre ou, très proches celles de Guéret regrettant de n'avoir su parler à Angèle dans Léviathan. Le thème de la prison qui dominait les premiers romans greeniens ... retrouve ici toute sa force. (Il:1555)

Jean Cassou, cited in Julien Green par lui-même by Robert de Saint Jean, observes of Green's characters that: “Chacun demeure enfermé dans son 
existence comme dans une manie. C'est que chacun a peur. Peur de luimême et peur du monde" (87).

For Philippe (Epaves), as for the other characters of Green, the only escape is madness or death. Since he did not have the courage to drown himself, as he would have liked to do, Philippe is condemned to a tightly circumscribed life. Dominique Van Hooff describes the bleakness of his world his prison:

Ces paysages mélancoliques de Paris, les eaux noires et boueuses de la Seine qui l'attirent comme un gouffre, . . . et ce ciel aveugle ne livrera aucun message de délivrance, aucune direction précise à cet homme dont la vie frivole et inutile ne semble avoir aucun sens. (4)

Most of Green's characters, like Fabien in Si j'étais vous, realize that their lives are excruciatingly painful: "Ahl n'être plus moi-même murmura-t-il, cesser d'être moi-même pendant une heure, fausser compagnie à ces éternels débats!" (866). Unfortunately for these individuals, acknowledging their misery does nothing to alleviate it; shackled by their upbringings, they are incapable of making any changes that might ameliorate their situations. Nicholas Kostis wrote of the characters in Léviathan: "Not only Guéret and Angèle, but both the other major characters are prisoners, somehow, of a structure, no matter whether it has been contructed by themselves or imposed upon them" (44).

Green often uses the window as a symbol of the prison to which his characters are confined. Daniel's aunt in Le Voyageur sur la terre passes the greater part of each day at the window. In Christine, Jean watches through the 
window as his mother and aunt return to the house with the doctor and then later he watches as the aunt and his cousin leave. He suspects something dreadful is taking place but neither his aunt nor his mother will discuss it with him. Childish imagination being what it is, he assumes that somehow his breaking of the rule prohibiting him from speaking to Christine ultimately led to her death. The window symbolizes how Jean is shut out from many important things that take place in families (as children frequently are). It is naive of grownups to think the children are not aware of what is going on. The problem is that without the proper explanations from the adults, the little ones are forced to construct their own explanations. Both Adrienne and Germaine Mesurat spend considerable time gazing out windows, "Le moindre bruit dans la rue la (Adrienne) faisait revenir à elle et l'attirait aussitôt à la fenêtre" (I: 306). Germaine, who is ill, reclines daily on a canape placed near a window which looks out on to the street:

Un long canapé avait été placé aussi près de la fenêtre que possible, de telle façon qu'il était impossible de voir la personne qui s'y était étendue mais cette personne avait replié ses jambes et l'on apercevait une main petite et maigre qu'elle avait posée sur ses genoux. (l: 288)

In Si j'étais vous, Fabien finds solace in the vista which lies outside an upper story window:

Il monta encore un étage et par une fenêtre entrouverte plongea son regard dans la grande cour pavée dont les pierres semblait dormir. Cette vue l'apaisa. Depuis près de trois ans, il voyait chaque soir les rangées d'orgueilleuses fenêtres ... (843) 
In Léviathan, Gueret senses that he is not free, even though he would be at a loss to identify what is restraining him. While tutoring the Grosgeorge child, he looks out the window at the storm taking place and thinks: "Une mince plaque de verre le séparait de l'air frais et vif, des cris du vent dans les arbres; une vitre, il n'en fallait pas plus pour qu'il se sentit prisonnier" (I: 310-311). Mme. Londe, as Nicholas Kostis points out, "never seeks to disengage herself from a situation she has devised and by which she eventually finds herself victimized, does not venture beyond the window of her house from which she watches the people who pass by" (44).

The window is a very effective device for visualizing the alienation of Green's characters. From within their self-made prisons, they look out on the wider world, powerless to leave their places of safety and enter it. In Les Clefs de la mort, Jean recognizes that he is a prisoner of his situation. He said: "Je suis pareil à une prison trop étroite habitée par un prisonnier monstrueux qui en ébranle les murs de son épaulen (539-540). As a result, he consciously tries to flee - to free himself: "Plutôt que de rester dans cette maison où l'ombre est enfermée comme un trésor, j'aime mieux me promener dans l'air brûlant . . ." (527). Denis in L'Autre Sommeil feels emprisoned by his existence. Robert Ziegler says of him:

Denis feels trapped inside a tired family history: he sees himself as an unwilling part of some generational continuum. His mother's imposition of her thoughts and her appearance makes him feel that she has robbed him of his personal autonomy: "Il y avait quelque part dans mon esprit 
je ne sais quoi qui m'apparentait à elle. De Telles pensées me soulevaient de fureur." He experiences her death as a manner of release, an attaining of the uniqueness that was denied him until then. (Authored Child. Fathered Text 5160)

Since one of the goals of traditional pedagogy is to quash any indications of individuality, children raised in such a system truly can not know themselves or be themselves. Dominique Van Hoof writes, "Le héros greenien est totalement inconscient de ses limites et le 'connais-toi, toi-même' de Socrate lui est parfaitement étranger" (127). Denis in L'Autre Sommeil laments, “... je désirais passionnément me connaître” (853). Tragically, few are ever able to become their unique selves even after the deaths of their parents. Green wrote of Philippe in Epaves:

Il avait dix huit ans à la mort de son père, mais la crainte du vieillard le tenait encore sans qu'il s'en rendit compte. On lui avait appris dans sa jeunesse à s'effacer devant cet homme silencieux et droit. (48)

Further on, Green adds:

Oubliait-il ses frayeurs d'enfant, la crainte de son père, cette crainte presque surnaturelle qui le poursuivait jusqu'ici? Jamais il ne prenait la parole dans cette salle sans qu'une voix de lui seul entendue essayât de le faire taire. De là venaient ses bredouillements et son embarras chaque fois qu'il s'agissait d'exprimer un avis. (86-87)

It is not easy to escape a prison constructed by traditional pedagogy since the constraints are in the mind of the prisoner. Like Philippe, Adrienne can not evade the domination of her sister and father even when her sister has left and her father is dead. Unfortunately their separate departures from her life 
do not free her from the effects of their autocratic cruelty. She must go mad to escape that. For Angele of Leviathan, death is the only escape from her prison. Robert Zielger writes:

At the conclusion of Leviathan there is a sundering of the bonds that have held Angele a captive of others for so long: "Les derniers liens se rompaient" as Green describes her worsening state (813). Yet here it is only death that frees the character from these ties. (Time and Others in Julien Green's Léviathan 75-84)

So it is with many of Green's characters; they can only escape their prisons through insanity or death. In these situations, death begins to take on positive overtones. It is not something to be feared or dreaded but rather something to be desired, for it is the means of escaping the pain, fear, and uncertainty from which their lives have been fabricated.

In Le Voyageur sur la terre the story of Daniel is an illuminating account of someone so totally unprepared to cope with the challenges of life that the only solutions available to him are madness and death. He was raised by a taciturn uncle, who closeted himself in his study day and night, and his eccentric aunt, who never seems to have left her post at the window. Seated at the window knitting, she would fill her young nephew's mind with frightful tales and confidences of all kinds, “Ma tante oubliait sans doute que je n'avais pas douze ans. .." (23). Living with two recluses did not afford Daniel many opportunities to leave the house. He, like the majority of Green's characters, exists rather than lives. Then, quite unexpectedly, his aunt's father oifers him the chance to escape and go to the university. He accepts and leaves without telling his uncle 
and his wife; but Daniel is ill-equiped to face the challenges of an ordinary life. In order to alleviate his extreme state of anxiety, the result of his suddenly being on his own in a world about which he knows or understands so little, his mind invents someone to help him - to guide him - Paul. Daniel even attributes the burning of his books to Paul whereas the reader later discovers it was his landlady. So desperate is Daniel for someone to help him, that he cannot feel any anger towards Paul for burning his books or taking his money. This is a phenomenon not unlike that of small, helpless children who are beaten by their parents but who nevertheless continue to adore these adults because they know their very existence is dependent on them. The children rationalize, "I deserved it, he or she was only trying to teach me a lesson." So Daniel had to justify Paul's actions:

J'avais mon voleur devant moi, j'en étais sûr, et cependant que me disais-je? A peu près ceci: "ll est bon et c'est à lui que je dois demander de te venir en aide. Ce qu'il a fait est sans importance." (48)

Daniel was terrorized by life to such an extent that it did not matter what Paul did as long as he stayed with him. Daniel did not realize that in fact by stealing his money, Paul not only was not protecting him, he was creating the very kinds of problems which rendered Daniel's life more precarious and difficult. Many have interpreted Daniel's dream, where he sees his own body lying on the bed and then feels himself leaving his body, as a desire for death: "II me semble que je m'étais rendu libre et me précipitant vers la porte, j’abandonnai le corps étendu sur le lit" (47). 
The dream is not as much a longing for death as it is a longing to escape life. A body represents life. Although Green seems to see death as freeing the soul from the body, Manuel in Le Visionnaire finds peace in repudiating any ideas of an everlasting soul. He realizes that being liberated from his religious beliefs freed him from his fear of death. What he had actually been fearing about dying was the idea of having to go on living. When he no longer believed that would be the case, he was at peace:

"Depuis quelques semaines, en effet, je me libérais peu à peu, de mes craintes anciennes; en reniant mon héritage catholique, je trouvais un réconfort étrange dans l'espoir de disparaître à jamais. L'idée de revivre me fatiguait, me terrifiait, ..." (468)

The atmosphere of death which pervades Le Visionnaire is a result of the psychological pain and the cruelties the characters inflict on one another. It is similar to what Jean-Paul Sartre describes in his play, Huis clos, "l'enfer, c'est les autres." The result of such emotional battering is death of the soul which can be argued to be worse than death of the body. Philippe's (Epaves) soul is dead. He too views death as a release from the agony of living:

Un refuge lui était ouvert. Seul le passage de la vie à la mort lui semblait difficile. Il essaya d'imaginer l'état d'esprit d'un homme assez courageux pour plonger dans ce fleuve glacial, sous cette brume, et accepter ensuite deux ou trois minutes de suffocation horrible. Mais, la frontière une fois traversée, commençait la nuit bienheureuse de l'anéantissement. (201)

M. Edme in Minuit thought he had a better solution than death. He established Frontfroide as a sanctuary from the vicissitudes of life: "Mes amis, dit tout à 
coup M. Edme, cette maison . . . est là le vrai refuge contre les terreurs de cette vie" (599). Unfortunately, in Green's world, there is only one refuge from the terrors of life and it is not to be found in Frontfroide. It is only in escaping Frontfroide that Elizabeth and Serge find deliverance as they fall to their deaths.

Unable to go on living following his wife's death, Bertrand Lombard (Varouna) descends into madness from which he is eventually delivered by death. Fabien (Si j'étais vous) dies, as does Manuel (Le Visionnaire). For Jean and Hedwidge in Le Malfaiteur and Blanche in Minuit, the cruelty of others leads them to seek the escape offered by suicide. Wilfred (Chaque homme dans sa nuit), torn between physical desire and the desire to be a saint, finds his deliverance in death. Christine dies in Christine and Emily (Mont-Cinère), who is irreparably handicapped by her strange upbringing, is rescued by death from the nightmare that is her life. In Green's world, the victims are accorded a release from their earthly prisons through death. Death is not seen as something to be feared but rather as an end to pain and suffering - a deliverance, a liberation.

Dr. M. Scott Peck, psychiatrist, philosopher, and author has written that: "Evil is that which kills spirit, life, or liveliness" (43). He then quotes Erich Fromm who classifies as evil: "those whose aim it is to avoid the inconvenience of life by transforming others into obedient automatons, robbing them of their humanity" (43). Such definitions can certainly be applied to traditional pedagogy. In Green's works, we have descriptions of the efforts of certain 
adults to subdue and subjugate the spirits of the children in their charge and then we see the impact it has on these children when they become adults. We witness the whole sequence: the destruction of emotions, self-esteem and independence, which results in loss of self confidence and necessitates control, which leads to withdrawal and isolation - a kind of self-imposed imprisonment, which can ultimately lead to violence, insanity, and death. 


\section{CONCLUSION}

Though Green does not discuss cruelty to children directly, it is obviously something which deeply troubles him, perhaps unconsciously. The studies of Jean Semolué led him to conclude:

Les confidences les plus importantes ne sont pas nécessairement les plus directes; les créations de Green le révelent plus que sa vie. Comme, dans l'histoire, les pensées et les espoirs des peuples comptent autant que les faits, l'univers mental de l'artiste compte autant que les actes de l'homme. Le caractère qu'il imprime à ses oeuvres exprime sa morale et sa psychologie plus que ne le ferait sa biographie. (15)

An entry in Green's journal seems to confirm this: "Il n'y a que ce que je passe sous silence qui s'exprime dans mes romans. (C'est même pour cela que mon vrai journal se trouve enfoui dans ce que j'invente)" (qtd. in Kostis 13).

Whether or not it was Green's intention to describe unhealthy parentchild relationships, a reader of his novels will find vivid descriptions of frightened, angry, ineffectual parents raising children who will in turn also be frightened, angry, and ineffectual. Traditional pedagogy is passed from one generation to the next and has been for centuries. Whoever reads Green's accounts will see this clearly in familial relationships like the one involving Mrs. Fletcher, her mother, and her daughter. Perhaps the biggest impediment to interrupting the perpetuation of the system has been the insistence on the idealization of parents. As a very young man, Green wrote the following about individuals burdened with ideas and myths passed down through the 
generations:

Les maximes qui ont aidé un homme à vivre peuvent tuer son fils, tant il est vrai que le respect dû à la mémoire des parents détermine parfois une sorte de suicide spirituel. Nous voyons tous les jours des hommes et des femmes dont le cerveau est plein d'opinions héritées qu'ils détestent sans même en avoir le soupçon le plus fugitif. En récompense, ils accableront leurs enfants comme ils ont été eux-mêmes accablés. (II: 1078)

It is important to realize that recognizing the existence of traditional pedagogy and its toxic effects is not about blame. It cannot be because the perpetrators are always victims first. They are not consciously trying to harm their children; they are simply doing what they think is best for them. They are following the teachings and examples of their own parents. Marie Therèse in Le Visionnaire recognizes that such was the case with her mother: "Mais on l'eût fort étonnée en lui apprenant qu'elle se montrait inhumaine envers moi; car elle croyait vouloir mon bien" (233). Alice Miller explains the parents' situation:

But where will you find human beings who are only good or only cruel? The reason why parents mistreat their children has less to do with character and temperament than with the fact that they were mistreated themselves and were not permitted to defend themselves. . such people suffer when their "hand slips", when an incomprehensible compulsion or despair induces them to shout at, humiliate, or beat their children and see their tears, yet they cannot help themselves and will do the same thing again next time. This will inevitably continue to happen as long as they persist in idealizing their own childhood. (For Your Own Good 105)

The parents in Green's novels struggle for the power and control they were 
denied as children. They use the same methods which were used on them - the parental look, the parental tone, humiliation, corporal punishment and manipulation. It is now acceptable for them to discharge the anger they were forced to suppress for so long. Being narcissistic, their first concerns will be for appearances and the right to exercise their authority.

Never able to be their unique selves, the victims of traditional pedagogy will experience little joy or happiness because when one trains oneself to repudiate emotions, there is no selectivity. It is difficult to think of a character in Green's novels who is happy or even contented. Daniel in Le Voyageur sur la terre describes his uncle: "Dans son visage décharné et vieilli je ne découvre rien d'un esprit généreux, rien d'un coeur charitable; tout y trahit la défiance, l'ennui et l'amertume d'un solitaire qui hait sa solitude" (21). In fact these unhappy individuals, who were never as children allowed to be spontaneous or to enjoy themselves, will resent any signs of happiness in their children and will try to shame said children for having been less than serious. Julien Green was the object of this phenomenon early in his life:

Lorsque j'étais fort jeune, il se trouva un écrivain catholique pour me dire tout uniment: "vous êtes le mal." Cela parce que j'étais heureux et qu'il ne l'était pas et qu'il aurait youlu l'être comme moi. II ne pouvait me le pardonner. En Enfer donc! C'est aussi simple que c'est atroce. (V: 620)

The author's extraordinary insight allowed him to see the situation clearly. It is possible that M. Green drew upon the experience cited above when he described Uncle Firmin as: 
D'avoir été si longtemps régenté lui-même exaspérait dans son coeur le goût de l'indépendance au point qu'il ne se sentait pas libre si d'autres l'étaient autour de lui ou témoignaient du désir de l'être. (II: 970-971)

Characters in Green's novels do not advance; they do not solve their problems or grow in any respect. They do not evolve because they are prisoners of lies and myths carefully inculcated by generations of parents or caretakers. Dominiqus Van Hooff notes: "A la différence cependant des héros de Camus ou de Sartre le héros greenien reste aveugle dans un monde sans la grâce et il n'est touché par aucune transformation" (115).

This is the tragedy of Green's characters - their inability to take charge of their lives, to find a way out of the situations in which they find themselves, to change and to grow. Their prisons are not physical; they are mental but more secure than concrete walls and bars. Physical restrictions alone cannot contain minds and spirits which can continue to develop and even soar. For the most part, Green's stories are constructed with desperately unhappy individuals. Incapable of feeling pain; they cannot feel joy. The souls of many of them are dead and their minds so weighted down with the effects of their strict traditional upbringings that growth or change is virtually impossible. Alone, angry, and perplexed, incapable of taking charge of their lives, they are forever searching for someone to validate their existences and rescue them from their prisons.

The ideas expressed by Green in his journal the seventh of March 1933 could well be applied to the tenets of traditional pedagogy:

... mieux vaut renier les augustes mensonges dont on 
nous a nourris sous le couvert du patriotisme et de la religion et tâcher de devenir simplement un homme. Aujourd'hui ma conviction profonde est que tant que I'homme n'abjurera pas certains mythes, il n'avancera pas. (IV: 229)

The methods advocated for centuries to train and educate children use myths as their justification. These myths deify parents and demonize children; they vilfy pride and normal healthy emotions while promoting control as a virtue. Mr. Green is absolutely correct. We will never advance as a civilization until we recognize and discard as untrue, certain beliefs with which we have been imbued. Mr. Green's objective and realistic portrayals of families are an unforgettable indictment of the very characteristics seen as virtues by so many parents and educators. Unless we renounce the destructive powers of the old precepts of child-rearing, society will never be able to overcome many of its most serious problems: crime, drug abuse, homelessness, mental iliness and war - all of which stem from feelings of shame, inferiority, hopelessness, and anger. 


\section{BIBLIOGRAPHY}

\section{WORKS BY JULIEN GREEN}

Les Pays Lointains. Paris: Seuil, 1989.

Les Etoiles du Sud. Paris: Seuil, 1989.

L'Expatrié. Paris: Editions du Seuil, 1990.

Oeuvres Complètes. Volumes I-VI. Paris: Gallimard, Bibliothèque de la Pléiade, 1972-1985.

Volume I (1972)

Christine

Le Voyageur sur la Terre

Mont-Cinère

Léviathan

Adrienne Mesurat

Les Clefs de la Mort

L'Autre Sommeil

Pamphlet contre les Catholiques de France

Articles, Documents, Notes

Volume II (1973)

Epaves

Le Visionnaire

Minuit

Varouna

Si J'étais Vous

Appendices, Articles, Notes

Volume III (1973)

Moïra

Le Malfaiteur

Chaque Homme dans sa Nuit

L'Autre

Appendices, Notes 
Volume IV (1975)

Journal:

Les Années Faciles (1926-34)

Derniers Beaux Jours (1935-39)

Devant la Porte Sombre (1940-42)

L'Oeil de l'Ouragan (1943-45)

Le Revenant (1946-50)

Le Miroir Intérieur (1950-54)

Le Bel Aujourd'hui (1955)

Notes, pp. 1475-1820.

Volume V (1977)

Journal:

Le Bel Aujourd'hui (1956-57)

Vers L'Invisible (1958-66)

Ce qui reste de Jour (1966-72)

Autogiographie:

Partir avant le Jour

Mille Chemins Ouverts

Terre Lointaine

Jeunesse

Notes

Volume VI (1990)

Journal:

La Bouteille à la Mer (1972-1976)

La Terre est si Belle (1976-1978)

La Lumière du Monde (1978-1981)

Oeuvres autobiographiques:

Quand Nous habitions tous Ensemble

Fin de jeunesse

Preface au "Visionnaire"

Ce qu'il faut d'amour à l'homme

Articles, Reportages, Entretiens and Notes

\section{CRITICAL WORKS ON JULIEN GREEN}

Burne, Gleen S. Julien Green. New York: Twayne Publishers, Inc., 1972. 
Dunaway, John M. The Metamorphoses of the Self. Kentucky: University Press of Kentucky, 1978.

Kostis, Nicholas. The Exorcism of Sex and Death in Julien Green's Novels. The Netherlands: Morton \& Co. N.V., 1973.

Newbury, Anthony H. Julien Green: Religion and Sensuality. Amsterdam: Rodopi, 1986.

Field, Trevor. "Julien Green and the Maternal Presents." French Studies Bulletin: a Quarterly Supplement 28 (1988): 1-3.

Piriou, Jean-Pierre J. Sexualité Religion et Art chez Julien Green. Paris: Editions A.-G. Nizet, 1976.

Petit, Jacques. Julien Green, avec des propos en marge de Julien Green. Paris: Desclee de Brouwer, 1972

Raclot, Michèle. Le Sens du Mystère dans l'oouvre romanesque de Julien Green. Paris: Aux amateurs de livres, 1988.

Rose, Marilyn Gaddis. "God's Tempter: The Devil and Julien Green." Claudel Studies 13 (1986): 74-80.

Saint Jean, Robert de. Julien Green par lui même. Paris: Editions de Seuil, 1967.

Sémolué, Jean. Julien Green ou l'obsession du mal. Paris: Edition du Centurion, 1964.

Stokes, Samuel. Julien Green and the Thorn of Puritanism. New York: Kings Row Press, 1955.

Tamuley, Annette. Julien Green à la recherche du réel - approche phénoménologique. Sherbrooke: Naaman, 1976.

Van Hooff, Dominique Marie. Julien Green et la peinture, ou le livre d'images du visionnaire. Diss. Brigham Young U, 1981. Ann Arbor: UMI, 1981. 8208401 .

Wildgen, Kathryn E. "A Portrait of the Artist, Creative Vision in Adrienne Mesurat." Romance Notes Winter 1984: 95-101. 
--.. "Green, Gide, and Claudel: Mutual Perceptions." Claudel Studies 13 (1986): 74-80.

Ziegler, Robert. "Authored Child Fathered Text: A Reading of Julien Green's Memories of Happy Days." Essays in French Literature 24 (1987): 51-60.

-.-. "Authorial Self-Suppression in Julien Green's Varouna." Romance Quarterly 36 (1989): 179-187.

--.. "In the Eyes of the Father: Narcissism and Identification in Julien Green's Chaque homme dans sa nuit." University of Davton Review 20 (1989): 99-107.

--.. "The Writer's Identity as Self-Dismantling Text in Julien Green's, Si j'étais vous." Studies in Twentieth Century Literature 14 (1990): 159-173.

-.-. "Time and Others in Julien Green's Leviathan." University of Dayton Review 18 (1987):75-84.

\section{CRITICAL WORKS ON EMOTIONAL DEVELOPMENT}

Bradshaw, John. The Family. Florida: Health Communications, Inc., 1988.

Curran, Dolores. Traits of a Healthy Family. New York: Ballantine Books, 1983.

Erikson, Erik H. Childhood and Society. New York: W. W. Norton \& Company, 1950.

Forward, Susan. Toxic Parents. New York: Bantam Books, 1989.

Masterson, James F. The Search for the Real Self. New York: The Free Press, A division of Macmillan Inc., 1988.

Miller, Alice C'est cour ton bien. France: Editions Aubier, 1983. 
--.. For Your Own Good. New York: Farrar, Straus and Giroux, 1983.

---. The Drama of the Gifted Child. New York: Basic Books, Inc., 1981.

--. Thou Shalt Not be Aware. New York: Farrar,Straus and Giroux, 1984.

Peck, M. Scott. People of the Lie. New York: Simon \& Schuster, 1983.

Ralston and Gage. Present Day Psychology. Philadelphia: Lippincott Company, 1931.

Rutschky, Katherine. Schwarze Pâdagogik Black Pedagogy. Bertin: Ulistein, 1977.

\section{IV: OTHER WORKS CONSULTED}

Conrad, Joseph. The Heart of Darkness. Middlesex: Harmonds - Worth, 1983.

Pernoud, Régine. La Reine Blanche de Castille. Paris: Albin Michel, 1972.

Sartre, Jean Paul. Huis clos. Paris: Editions Gallimard, 1947. 